\title{
Phytolith Assemblages Along a Gradient of Ancient Human Disturbance in Western Amazonia
}

\section{OPEN ACCESS}

Edited by:

Simon Haberle,

Australian National University, Australia

Reviewed by:

Encarni Montoya,

The Open University, UK

Juanma Rubiales,

Universidad Politécnica de Madrid,

Spain

*Correspondence:

Crystal H. McMichael

c.n.h.momichael@uva.n

Specialty section:

This article was submitted to

Paleoecology,

a section of the journal

Frontiers in Ecology and Evolution

Received: 03 September 2015 Accepted: 27 November 2015

Published: 17 December 2015

Citation:

McMichael CH, Piperno DR,

Neves EG, Bush MB, Almeida FO,

Mongeló $G$ and Eyjolfsdottir $M B$

(2015) Phytolith Assemblages Along a

Gradient of Ancient Human

Disturbance in Western Amazonia.

Front. Ecol. Evol. 3:141.

doi: 10.3389/fevo.2015.00141

\begin{abstract}
Crystal H. McMichael 1,2*, Dolores R. Piperno ${ }^{3,4}$, Eduardo G. Neves ${ }^{5}$, Mark B. Bush ${ }^{2}$, Fernando O. Almeida ${ }^{6}$, Guilherme Mongeló ${ }^{5}$ and Margret B. Eyjolfsdottir ${ }^{2}$

${ }^{1}$ Palaeoecology and Landscape Ecology, Institute for Biodiversity and Ecosystem Dynamics, University of Amsterdam, Amsterdam, Netherlands, ${ }^{2}$ Department of Biological Sciences, Florida Institute of Technology, Melbourne, FL, USA, ${ }^{3}$ Smithsonian Tropical Research Institute, Panama, Panama, ${ }^{4}$ Department of Anthropology, National Museum of Natural History, Smithsonian Institution, Washington, DC, USA, ${ }^{5}$ Laboratório de Arqueologia dos Trópicos, Museu de Arqueologia e Etnologia, Universidade de São Paulo, São Paulo, Brazil, ${ }^{6}$ Departamento de Arqueologia, Universidade Federal de Sergipe, Aracaju, Brazil
\end{abstract}

The ecological status of prehistoric Amazonian forests remains widely debated. The concept of ancient Amazonia as a pristine wilderness is largely discredited, but the alternative hypothesis of extensive anthropogenic landscapes remains untested in many regions. We assessed the degree of ancient human impacts across western Amazonia based on archeological and paleoecological data using methodologies that would allow inter-regional comparisons. We also aimed to establish baselines for estimating the legacies of ancient disturbances on modern vegetation. We analyzed charcoal and phytolith assemblages from soil samples from an archeological site, sites in close proximity to archeological sites, sites from riverine and interfluvial forests, and a biological research station believed to contain some of the least disturbed forests within Amazonia. We then quantitatively compared phytolith assemblages within and between the surveyed regions. Palm enrichment was evident at the archeological site, and the biological station survey contained little to no evidence of ancient human activity. The other sites exhibited a gradient of ancient disturbance across the landscape. The phytolith assemblages showed statistically significant between-region variations that indicated our metrics were sufficiently sensitive to detecting ancient disturbance. Our data highlight the spatial heterogeneity of ancient human disturbances in Amazonian forests. The quantification of these disturbances provides empirical data and a more concrete link between the composition of the modern forest and ancient disturbance regimes. Accounting for ancient disturbances will allow a deeper understanding of the landscape heterogeneity observed in the modern forests.

Keywords: Amazonia, ancient impacts, archeology, historical legacies, paleoecology, pre-Columbian, vegetation dynamics

\section{INTRODUCTION}

Tropical rainforests are a test bed for ecological research linking species diversity and distributions with the ecological niche (Elton, 1927; Hutchinson, 1957; Whittaker et al., 1973; Clark et al., 1999) and neutral dynamics (Terborgh, 1992; Hubbell, 2001; Tuomisto et al., 2003). Assumptions that the forests are at equilibrium, or nearly so, underlie much of this research. Yet recently 
several researchers have suggested that vegetation patterns in Amazonian forests largely result from pre-Columbian people (Balée, 1989, 1993, 2010; Clark, 1996; Clement, 2006; Levis et al., 2012; Roosevelt, 2013; Clement et al., 2015), and that no-analog assemblages were created that did not exist prior to human intervention (Balée, 2014). Tree generations in Amazonian forests commonly span over 150 years (Hartshorn, 1978). If past human activity was both site-intensive and spatially widespread, and ancient people created a "manufactured landscape," then the ecological assumptions of current forest equilibrium become questionable. A manufactured landscape also infers that Amazonian biodiversity patterns were recently (i.e., the last two millennia) configured to their current distributions, and species diversity should be correlated with distributions of ancient people. Testing these ideas with empirical data would add an additional level of depth to the current understanding of Amazonian ecology and biodiversity.

Humans have been present as hunter-gatherers in Amazonia throughout the Holocene (Roosevelt et al., 1991, 1996; Lombardo et al., 2013). The earliest documented maize cultivation in Amazonia occurred at Lake Ayauch ${ }^{\mathrm{i}}$ in Ecuador at ca. 6000 cal year BP (Bush et al., 1989). After 2500 cal year BP, evidence of agriculture (Piperno, 2007, 2011) and other forms of human activity, including fire frequency, dramatically increased in Amazonia (Bush et al., 2008; Marlon et al., 2008). Soil amendments and the creation of anthropogenic soil types, called terras pretas, became more frequent during the last 2000 years (Neves et al., 2004; Neves and Petersen, 2006). Perhaps most impressively, landscape transformations in the form of earth moving began. Tracts of earthworks, raised fields, and berms appeared in the Upper Xingu region of Brazil and Llanos de Moxos region of Bolivia (Erickson, 2000, 2006; Heckenberger et al., 2003, 2008). Geometrically-shaped earthworks, commonly referred to as geoglyphs, also began to appear in portions of the southwestern Amazon (Ranzi et al., 2007; Pärssinen et al., 2009; Schaan et al., 2012) and at Marajó island as well (Roosevelt, 2013).

This evidence refutes the idea that Amazonia was a pristine forest prior to European discovery because of environmental limitations, particularly poor soils, which prevented ancient people from advanced societal development (Meggers, 1957, 1971). A more moderate view is that the human footprint in Amazonia was heterogeneous, but the extent of that heterogeneity remains debatable (McMichael et al., 2012a; Bush et al., 2015; Clement et al., 2015). At the opposite extreme of Meggers is the idea that most of Amazonia was a manufactured landscape only a few hundred years ago (Erickson, 2006; Roucoux et al., 2013). A first step in addressing the extent to which Amazonia was a manufactured landscape is to assess the sensitivity of proxy records across a range of settings, both with and without ancient human disturbance.

Here, we took an interdisciplinary approach (e.g., Mayle and Iriarte, 2014) and compared phytolith assemblages, a proxy for vegetation, from a known archeological site containing abundant pottery sherds and the presence of terra preta soils with: (1) phytolith assemblages from Cocha Cashu Biological Research Station, which contains some of the oldest and possibly most pristine forests remaining in Amazonia, and (2) phytolith assemblages from sites across western Amazonia containing a range of ancient disturbances (McMichael et al., 2012a,b,c, 2013; Figure 1). We identified trends in phytolith assemblages from the bottom to top of cores, and looked at the magnitude of change of phytolith percentages within cores and across regions. We then generated an index of past human impacts for the regions surveyed, which can be used in assessments of modern vegetation patterns in Amazonian forests.

\section{METHODS}

\section{Site Descriptions}

All sites are located in lowland Amazonian forests (Figure 1, Table 1). New data are presented from the Teotônio archeological site, and the Cocha Cashu Biological Research Station, which are used to establish baseline values for occupied (Teotônio) and non-occupied (Cocha Cashu) sites (see below). The other sites contain soil cores that were previously analyzed for charcoal and phytoliths in a qualitative manner, and further information on the experimental design and site selection can be found in the original publications (McMichael et al., 2012a,b,c, 2013). Here, these data are analyzed quantitatively to derive estimates of the degree of ancient human impacts compared with Teotônio and Cocha Cashu. All dates presented have been calibrated using IntCal 13 (Reimer et al., 2013). After the Cocha Cashu and Teotônio site descriptions, all other sites are presented in alphabetical order.

The Cocha Cashu Biological Research Station $(-11.9,-71.37)$ is located on lowland floodplain forests on rich alluvial soils and terra firme forests within Manu National Park in Peru. These forests receive $2100 \mathrm{~mm}$ of rain per year, most of which falls in October to May. Tree plot data from Cocha Cashu contain over 1215 tree species, documenting it as one of the most diverse and believed to be most pristine locations within Amazonia (Foster, 1990; Gentry and Terborgh, 1990; Pitman et al., 1999;

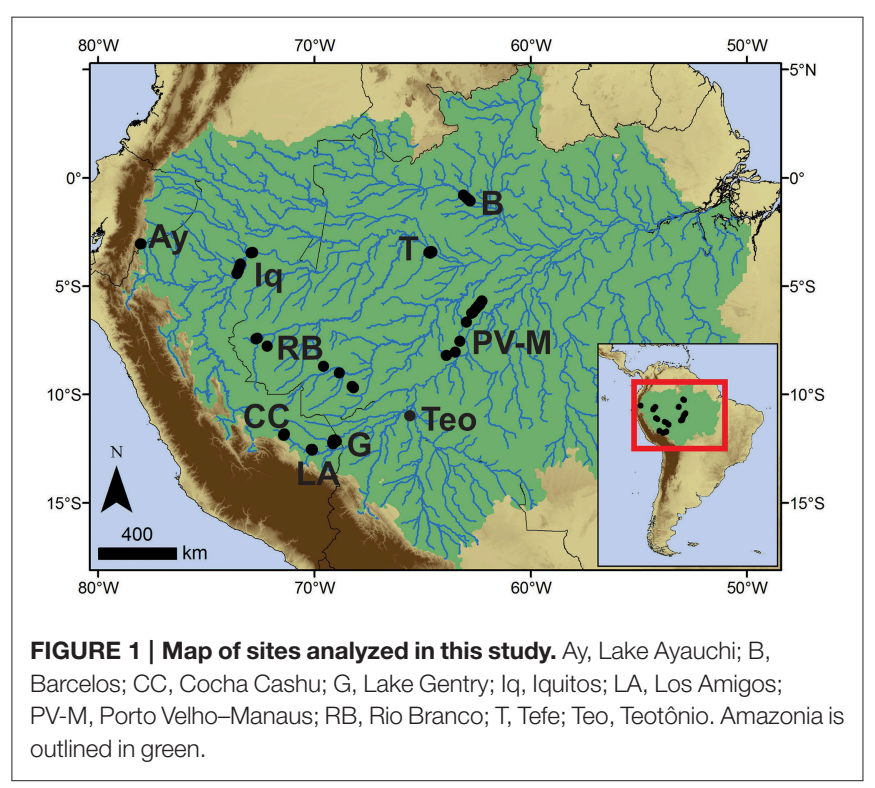


TABLE 1 | Sampling effort for each region included in the analysis.

\begin{tabular}{|c|c|c|c|c|c|}
\hline \multirow[t]{2}{*}{ Location } & \multicolumn{2}{|c|}{ Phytolith data } & \multirow[t]{2}{*}{ Agriculture } & \multirow{2}{*}{$\frac{\text { Charcoal data }}{\text { Total cores }}$} & \multirow{2}{*}{$\frac{\text { Archeological data }}{\text { terras pretas }}$} \\
\hline & Total cores & Total samples & & & \\
\hline Teotônio & 1 & 11 & 1 & 2 & yes \\
\hline Barcelos $^{a}$ & 3 & 11 & 0 & 31 & yes \\
\hline Tefe $^{a}$ & 10 & 39 & 0 & 40 & yes \\
\hline Ayauchib $^{\mathrm{b}}$ & 11 & 58 & 1 & 15 & no \\
\hline Gentryb & 10 & 78 & 1 & 79 & no \\
\hline Porto Velho-Manaus ${ }^{a, c}$ & 16 & 50 & 1 & 52 & no \\
\hline Rio Branco ${ }^{a}$ & 2 & 18 & 0 & 10 & no \\
\hline Los Amigos $^{a}$ & 3 & 13 & 0 & 74 & no \\
\hline Iquitos $^{a}$ & 3 & 7 & 0 & 40 & no \\
\hline Cocha Cashu ${ }^{d}$ & 1 & 9 & 0 & 37 & no \\
\hline
\end{tabular}

"Total samples" is the total number of samples (depth intervals) that composed the cores analyzed. Previously published data are from: ${ }^{2} \mathrm{McMichael}$ et al. (2012a); ${ }^{\mathrm{M}} \mathrm{McMichael}$ et al. (2012b); " Piperno et al. (2015); and ${ }^{d}$ McMichael et al. (2013).

Silman et al., 2003). The floodplain forests behind the oxbow are believed to be $>400$ years old, with the interior forests likely much older (Silman and Krisel, 2006). No fire has been documented in the reserve in the last 45 years of continuous monitoring, and the only charcoal to come out of sediment cores from Cocha Cashu were derived from wood burned at the station after 1968 (Bush et al., 2007). Additional sets of sediment cores from nearby oxbow lakes contain no charcoal over the past 220-700 years (Listopad, 2001). New charcoal data are reported here from 37 soil cores spread across 10 sites within the oldgrowth forests of Cocha Cashu. Each core was collected at $10 \mathrm{~cm}$ intervals to a total depth of $80 \mathrm{~cm}$. Previously published phytolith data from the terra firme forest at Cocha Cashu were used in regional comparisons, though assemblages from bamboodominated forests were excluded from the analysis because of their own very distinguishable phytolith signature (McMichael et al., 2013).

The Teotônio archeological site $(-8.86,-64.06)$ is located on a river bluff on the Upper Madeira River in Brazil (Almeida and Neves, 2014). New charcoal data from two excavation pits and phytolith data from one of those pits are presented here, in sampling intervals from the soil surface down to a total depth of $120 \mathrm{~cm}$ in $10 \mathrm{~cm}$ intervals $(0-10 \mathrm{~cm}, 10-20 \mathrm{~cm}$, etc.) The site analyzed for phytoliths was composed of terra preta soils, and contained abundant pottery sherds, charcoal, and macrofossils, particularly in its upper layers (for additional details, see Almeida and Neves, 2014). Annual rainfall in the region ranges from 1800-3500 mm/year, with a dry season lasting from June through September that has $<50 \mathrm{~mm}$ of rainfall per month (de Freitas et al., 2001).

Lake Ayauch $^{\mathrm{i}}$ lies at $330 \mathrm{~m}$ above sea level on the eastern flank of the Andes, and is located above a floodplain that is within $2 \mathrm{~km}$ of Rio Santiago. The region receives $2000-3000 \mathrm{~mm}$ year $^{-1}$ of rainfall with $0-2$ months of dry season that supports dense tropical rain forest. Members of the Shuar nation currently inhabit the area, and they cultivate manioc, plantains, and papayas near the lake. The lake was cored in 1983 with a modified Livingstone piston-corer (Bush et al., 1989), and re-cored in 2007 to obtain sediment for high-resolution charcoal analysis
(McMichael et al., 2012b). Palaeoecological analyses of the lake sediments and surrounding soils revealed localized maize (Zea mays) cultivation around the lake that began ca. 5800 cal year BP, and intensified ca. 2500 cal year BP (Bush et al., 1989; McMichael et al., 2012b). The agriculture around Lake Ayauch ${ }^{\mathrm{i}}$ was also associated with fire. Charcoal in the lake sediment increased ca. 2000 cal year BP, and the frequency of dated fragments from soil charcoal was highest during the period from 2500 to 500 cal year BP (McMichael et al., 2012c). Raw phytolith data were previously published (McMichael et al., 2012b), but not analyzed using the metrics presented below or in inter-regional comparisons.

Barcelos and Tefe are located in the central Amazon in Brazil. Both areas contain terras pretas and have a known archeological history (Heckenberger and Neves, 2009; Aldrich and WinklerPrins, 2010). Barcelos sits atop a river bluff on the Rio Negro midway between Manaus and Sao Gabriel da Cachoeira, and receives $2500 \mathrm{~mm}$ /year precipitation, with a dry season from January to March (da Silva, 2008). Tefe is located on the southern side of the Solimões River, and receives ca. $2500 \mathrm{~mm}$ /year precipitation, with a dry season lasting from July to September (da Silva and Pinheiro, 2010). Soil cores from both of these regions contained abundant charcoal, and the highest frequency of dates was from 2000 to $500 \mathrm{cal}$ year BP (McMichael et al., 2012a). Phytolith data contained no evidence of agriculture, and little evidence of canopy opening at the sampled sites, which were located $>10 \mathrm{~km}$ from any known terra preta or archeological site (McMichael et al., 2012a).

Lakes Gentry and Parker (hereafter Gentry) are located at elevations of $200-300 \mathrm{~m}$, lie $>200 \mathrm{~km}$ from the Andes, and are located $>20 \mathrm{~km}$ away from the Madre de Dios River in southeastern Peru. A precipitation gradient extends across the Madre de Dios watershed, ranging from ca. $2000 \mathrm{~mm} /$ year $^{-1}$ in the north to ca. $1700 \mathrm{~mm} /$ year $^{-1}$ in the south. The duration of the dry season is typically 2-4 months. Lakes Gentry and Parker were cored in 1998 and 2001 (respectively) with a ColinvauxVohnout coring rig (Colinvaux et al., 1999). The sediment core from Lake Gentry contained Zea mays pollen beginning ca. 3500 cal year BP, and becoming more frequent from 2500 to $500 \mathrm{cal}$ 
year BP (Bush et al., 2007). The core from Lake Parker did not contain any evidence of maize agriculture, though it did contain charcoal (Bush et al., 2007). Soil cores retrieved from around the lakes contained localized evidence of fire, and maize phytoliths were found at only one site within $100 \mathrm{~m}$ of the edge of Lake Gentry (McMichael et al., 2012b).

Iquitos lies in the Peruvian state of Loreto, and typically receives $3400 \mathrm{~mm} /$ year with basically no dry season (1999-2005 data; Morrison et al., 2010). Lake Quistococha, an archeological site ca. $10 \mathrm{~km}$ south of Iquitos contains artifactual evidence of occupation from 1300 to 2500 cal. year BP (Rivas et al., 2006). Sedimentary sequences from nearby peats contain no evidence of human impact (Roucoux et al., 2013). Soil cores collected around the Iquitos region contained small, infrequent charcoal fragments (McMichael et al., 2012a). The only fragments that were sufficient size for ${ }^{14} \mathrm{C}$ AMS dating (1 mg weight) provided fire dates of 2600 and $1000 \mathrm{cal}$ year BP, and one modern date (McMichael et al., 2012a). No evidence of maize agriculture was found in the phytolith samples from Iquitos (McMichael et al., 2012a).

Los Amigos Biological Research Station is located at the confluence of the Madre de Dios and Los Amigos Rivers in southeastern Peru over $100 \mathrm{~km}$ away from Lakes Gentry and Parker. The area is also wetter, and receives $2700-3000 \mathrm{~mm}$ precipitation per year with a 3-5 month dry season (2000-2006 data; Pitman, 2008). Soil cores collected from the area contained evidence of fire over the last 4000 years, with increased frequency from 2000 to $500 \mathrm{cal}$ year BP (McMichael et al., 2012c). No maize phytoliths were found in the soil cores.

Porto Velho is located in central Amazonia in Brazil, and has the same climatic conditions as described for Teotônio. Terra preta sites have been found along the Rio Madeira in between Porto Velho and Manaus (Levis et al., 2012). Soil cores have been analyzed from an area located along BR-319, which connects the cities of Porto Velho to Manaus (e.g., Fearnside and de Alencastro Graça, 2009; hereafter PV-M). Charcoal was present in varying amounts in the PV-M samples, and maize phytoliths were found in one sample near Porto Velho (McMichael et al., 2012a; Piperno et al., 2015). These samples were collected at least $20 \mathrm{~km}$ away from any known terra preta or archeological site. Fourteen ${ }^{14} \mathrm{C}$ AMS dates were obtained from charcoal fragments in the PV-M cores. Five of the dates were from modern fires, and the remaining dates ranged from 2000 to $1000 \mathrm{cal}$ year BP, with one date of 3500 cal year BP (McMichael et al., 2012a).

Rio Branco is located in the Brazilian state of Acre, and the BR-164 traverses the state from Rio Branco in the east to Cruzeiro do Sul in the west. Annual rainfall near Rio Branco is ca. $1900 \mathrm{~mm} /$ year $^{-1}$. The dry season lasts from May to September and is most severe (i.e., $<60 \mathrm{~mm}$ per month) during June, July, and August (Fonseca Duarte, 2006). The region contains geometric earthworks, termed geoglyphs, that were mostly formed from 2000 to 700 cal year BP (Schaan et al., 2012). Soil cores collected along the BR-164 in closed canopy forests (hereafter Rio Branco) contained little charcoal and no maize phytoliths (McMichael et al., 2013). A single ${ }^{14} \mathrm{C}$ date of ca. 1900 cal year BP was obtained from the cores (McMichael et al., 2013).

\section{Laboratory Techniques}

The methodology of soil charcoal analysis followed standard techniques (McMichael et al., 2012c). Approximately $20 \mathrm{~g}$ of soil from each sample was used for charcoal analysis, though calculations of charcoal abundance were based off volumetric measurements of the soils to account for initial differences in soil moisture. Soils were deflocculated in Alconox detergent and shaken for $24 \mathrm{~h}$. Sediments were rinsed and sieved at $500 \mu \mathrm{m}$. Charcoal fragments were retrieved from the remaining sediments, and were photographed. The overall surface area of charcoal fragments was calculated for each sample (depth interval) using Image J Software. Surface area calculations were converted to estimates of charcoal volume per sample using the equations derived by Weng (2005).

Soil charcoal abundances, however, do not directly reflect fire parameters, but instead are a proxy for the presence or absence of fire (e.g., Clark and Patterson, 1997; Sanford and Horn, 2000). False positives in charcoal data (i.e., Type I error) may result from increased weathering and migration rates of charcoal particles through soil profiles (e.g., Carcaillet and Talon, 1996; Carcaillet and Thinon, 1996; Carcaillet, 2001), or from long distance transport of charcoal from more regional sources (e.g., Tinner et al., 2006). To reduce the likelihood of Type I error, we classified charcoal abundance measurements for each depth interval $\left(\mathrm{mm}^{3} / \mathrm{cm}^{3}\right)$ of each core as trace amounts $\left(<0.25 \mathrm{~mm}^{3} / \mathrm{cm}^{3}\right)$ or significant charcoal (hereafter referred to charcoal presence; $>0.25 \mathrm{~mm}^{3} / \mathrm{cm}^{3}$ ) (McMichael et al., 2012a,c). Trace values include one to several tiny charcoal particles ca. $500 \mu \mathrm{m}$ in size (smaller than a pinhead) found within a given sample. The categorization of charcoal presence is the equivalent of having larger-than-pinhead sized fragments present in a given sample, and is interpreted as an in situ fire event.

Phytoliths were extracted from ca. $20 \mathrm{~g}$ of soil using standard laboratory procedures (Piperno, 2006). Soils were deflocculated, clays were removed, and soils were sieved through nested 250 and $53 \mu \mathrm{m}$ sieves. Carbonates, organic matter, and humic acids were removed from the remaining sample material (0-53 and 53-250 $\mu \mathrm{m}$ fractions). Phytoliths were extracted from the remaining sediment by heavy liquid flotation using zinc bromide at a specific gravity of 2.3, and mounted on microscope slides using Permount mountant solution. The phytolith assemblages from the silt fraction $(0-53 \mu \mathrm{m})$ were quantified by identifying 200 phytoliths per sample, and extended scans were carried out to search for the presence of rarer phytolith types. Phytolith morphotypes and identifications were classified as arboreal forest elements (arboreal), grasses and early successional herbaceous taxa (herbs), or palms. Palms are classified separately because they have diagnostic phytoliths (Piperno, 2006) and are recognized as one of the plant types likely to have been promoted by human activity (Clement, 1988; Miller, 1992). For example, Bactris gasipaes, the peach palm, was one of the most widely cultivated palms by indigenous people (Clement, 1988, 2006; Clement et al., 2010). Other palm species were also promoted by indigenous societies (e.g., Balée, 1988, 1989). 


\section{Quantifying Past Disturbance and the Vegetation Response \\ Charcoal Data}

Charcoal presence was determined for each sample in each core for all of the regions, including the new data presented from Cocha Cashu and Teotônio. If any depth interval within a given core contained charcoal, the core was assigned as have charcoal presence. We then calculated the percentage of cores containing present charcoal for each region. Though the Teotônio site only contains one soil profile that was examined for charcoal, it is well established that macroscopic charcoal is frequently found in lowland Amazonian archeological sites, and is a required component for the formation of terras pretas (Neves et al., 2004; Neves and Petersen, 2006). Thus, we are confident in assigning 95\% as the likelihood of finding pinhead-sized charcoal in an ancient occupation site to use in statistical comparisons (see Section Multi-Proxy and Inter-Regional Comparisons of Ancient Disturbance).

\section{Phytolith Data}

We quantified percentages of arboreal, herb, and palm phytoliths for the Teotônio site. We then took those percentages and the previously published data from the other regions, and derived metrics of past vegetation change that could be compared within and between regions. Within-region variability was examined using boxplots that showed medians and quartiles of phytolith percentages of all samples within a region. To compare the regional values to the baseline sites of Teotônio and Cocha Cashu, which have only one core of phytolith data each (Table 1), we derived two core-level metrics that would allow the regional data to be compared with these sites. For each soil core, we calculated the trend of arboreal, herb, and palm phytoliths from the bottom to the top of the core (trend = surface-basal). The trend metric provided an estimate of the overall directionality of vegetation change through time. For the second metric, we used the maximum and minimum percentages of arboreal, herb, and palm phytoliths within each core to calculate the overall magnitude of change within that core (delta $=$ maximum-minimum). This metric captured the vegetation flux and variability of the phytolith assemblages within a given core. The trends through time and magnitude of change metrics for each region were compared with both Teotônio and Cocha Cashu, separately, using one-sample $t$-tests with Bonferroni corrections (Quinn and Keough, 2002).

\section{Multi-Proxy and Inter-Regional Comparisons of Ancient Disturbance}

Though age-depth relationships cannot be assumed in soils, several generalizations can be made regarding the temporal context captured by the soil charcoal and phytolith data. The first is that while reversals in dated material indeed occur in Amazonian soils, the majority of dated charcoal fragments within single cores or profiles have maintained a general stratigraphic integrity. A second consistent pattern is that the first $80-$ $100 \mathrm{~cm}$ of soil typically captures the last 3000-5000 years of fire history (Sanford et al., 1985; Piperno and Becker, 1996; Santos et al., 2000; Francis and Knowles, 2001; McMichael et al.,
$2012 \mathrm{a}, \mathrm{b}, \mathrm{c})$. The third generalization is that $95 \%$ of dated charcoal fragments recovered from depths below $20 \mathrm{~cm}$ are older than 500 years (i.e., pre-Columbian aged), though in the upper $20 \mathrm{~cm}$ of soil approximately half of the dated fragments were modernaged (McMichael et al., 2012c). Dated phytolith assemblages exhibit similar age - depth trends within a core as charcoal. The top meter of soil typically captures the last 3000-5000 years of vegetation history, though prehistoric-aged phytoliths are commonly found in the upper $20 \mathrm{~cm}$ of soil (McMichael et al., 2012a,b; Piperno et al., 2015). Here, we consider whether charcoal or changes in phytolith assemblages were found at any depth interval to ensure that we accounted for all pre-Columbian impacts on the Amazonian landscape. We do, however, realize that we are also likely capturing bits of historic period or modern disturbances in our analyses.

A "human impact score" was derived for each region based on the following lines of evidence contained within soil cores: (1) the presence or absence of a known archeological site (i.e., Teotônio), which includes sites containing terras pretas, earthworks, or pottery; (2) the presence or absence of agricultural pollen or phytoliths; (3) the number of cores per region that contained charcoal; (4) the magnitude of change of early-successional and grass taxa in a given core; (5) the magnitude of change of palm taxa within a given core; and (6) the total magnitude of change of arboreal taxa in a given core. The first two provide direct evidence of human activity, and were given a weighting of five (5). The third line of evidence is likely also a direct result of human activity and was given a weight of four (4). The last three provide indirect evidence (i.e., changes in vegetation that may or may not reflect human activity) and were given lower weights. We then used the weighted sum of all proxies as the "human impact score."

Terras pretas were found at the Teotônio site, but have also been found in the Barcelos and Tefe areas. Though the nearest known terra preta site is over $10 \mathrm{~km}$ from one of the soil sampling sites, Barcelos and Tefe were also assigned as having terras pretas when deriving the human impact score. Evidence of agriculture was found at Teotônio, and has also been found at Lakes Ayauch ${ }^{\mathrm{i}}$ and Gentry, and in one sample in the Porto Velho-Manaus region. Though fire is a known component of ancient human activity, and every sample from Teotônio contained abundant and large fragments of charcoal, we assigned Teotônio as having $95 \%$ of cores containing charcoal.

\section{RESULTS}

\section{Charcoal}

The Teotônio site had large and frequent charcoal fragments in every sample analyzed from 0 to $120 \mathrm{~cm}$ depth in each core. The survey at Cocha Cashu was conducted over an area of $8 \mathrm{~km}^{2}$, and only six of the 37 cores (16\%) contained macroscopic charcoal (Figure 2). When charcoal was found, it was in abundances just above the $0.25 \mathrm{~mm}^{3} / \mathrm{cm}^{3}$ threshold required to be considered present. Only two charcoal fragments recovered were large enough for ${ }^{14} \mathrm{C}$ AMS dating, and both were barely larger than the required size of $1 \mathrm{mg}$ dry weight. Those two fragments provided fire dates of $\sim 1400$ and 650 cal year BP, and were not recovered 


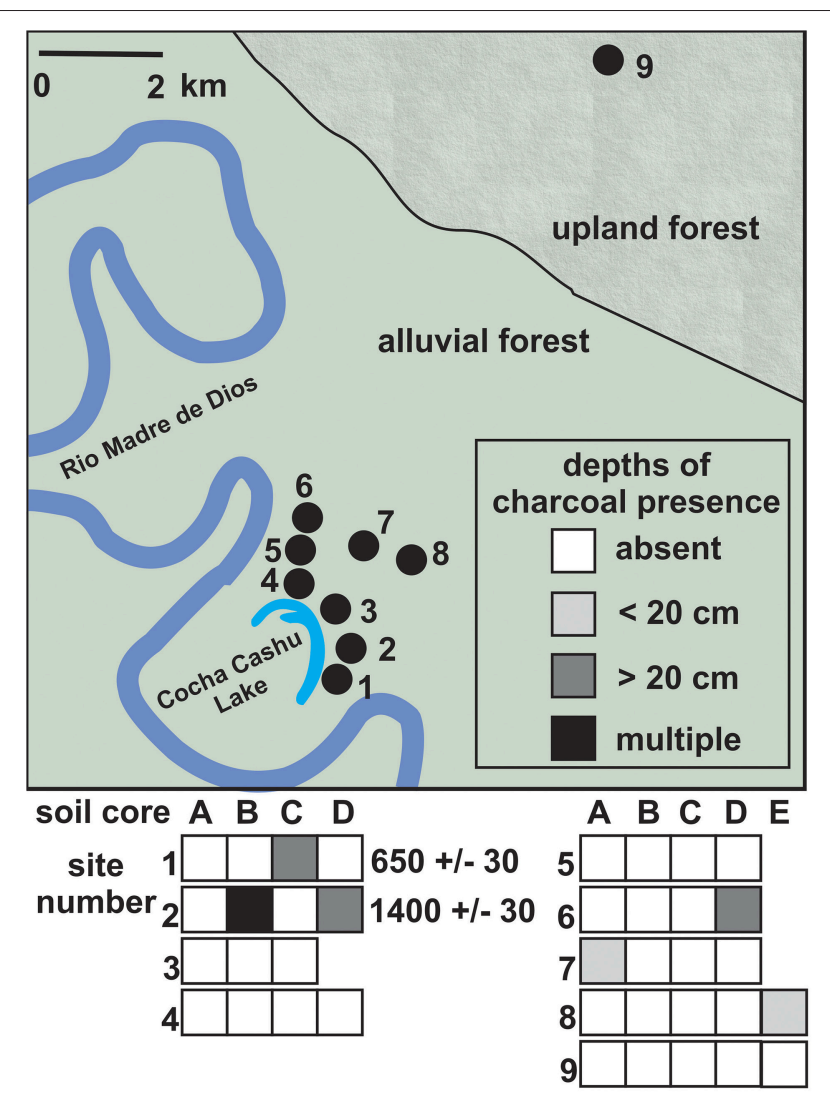

FIGURE 2 | Charcoal sampling locations (top) and charcoal frequency from 37 cores collected at $\mathbf{9}$ sites across the Cocha Cashu forest (bottom). Sites 1-8 were located on mature alluvial floodplain forest, and site 9 was located on closed canopy terra firme forest. The only two charcoal fragments recovered that were large enough for ${ }^{14} \mathrm{C}$ AMS dating were from Sites 1 and 2, near the oxbow lake. Colored boxes correspond with the depths at which the charcoal fragments were found (see legend).

from the same core that was used for phytolith reconstructions (Core 9).

The percentage of cores containing charcoal from other regions ranged from 23\% (Iquitos) to $90 \%$ (Barcelos). Barcelos and Tefe, which contain terras pretas within $10 \mathrm{~km}$ of the sampled locations (McMichael et al., 2012a), had the highest percentages of cores containing charcoal ( 90 and $75 \%$, respectively). The lake sites, Ayauch ${ }^{\mathrm{i}}$ and Gentry, and the Porto Velho-Manaus region, all of which contained evidence of maize agriculture, had ranges of cores containing charcoal from 62 to $67 \%$. The Rio Branco and Los Amigos regions in southwestern Amazonia contained charcoal in about half of the cores surveyed. Iquitos contained very little sign of charcoal, and very few fragments large enough for ${ }^{14} \mathrm{C}$ AMS dating, similarly to Cocha Cashu.

\section{Phytolith Assemblages at Cocha Cashu and Teotônio}

The phytolith assemblages from the Cocha Cashu were consistently dominated by non-palm arboreal morphotypes (Figure 3). Arboreal phytoliths accounted for $80-90 \%$ of the entire assemblage at all depth intervals. Herb phytoliths were rare
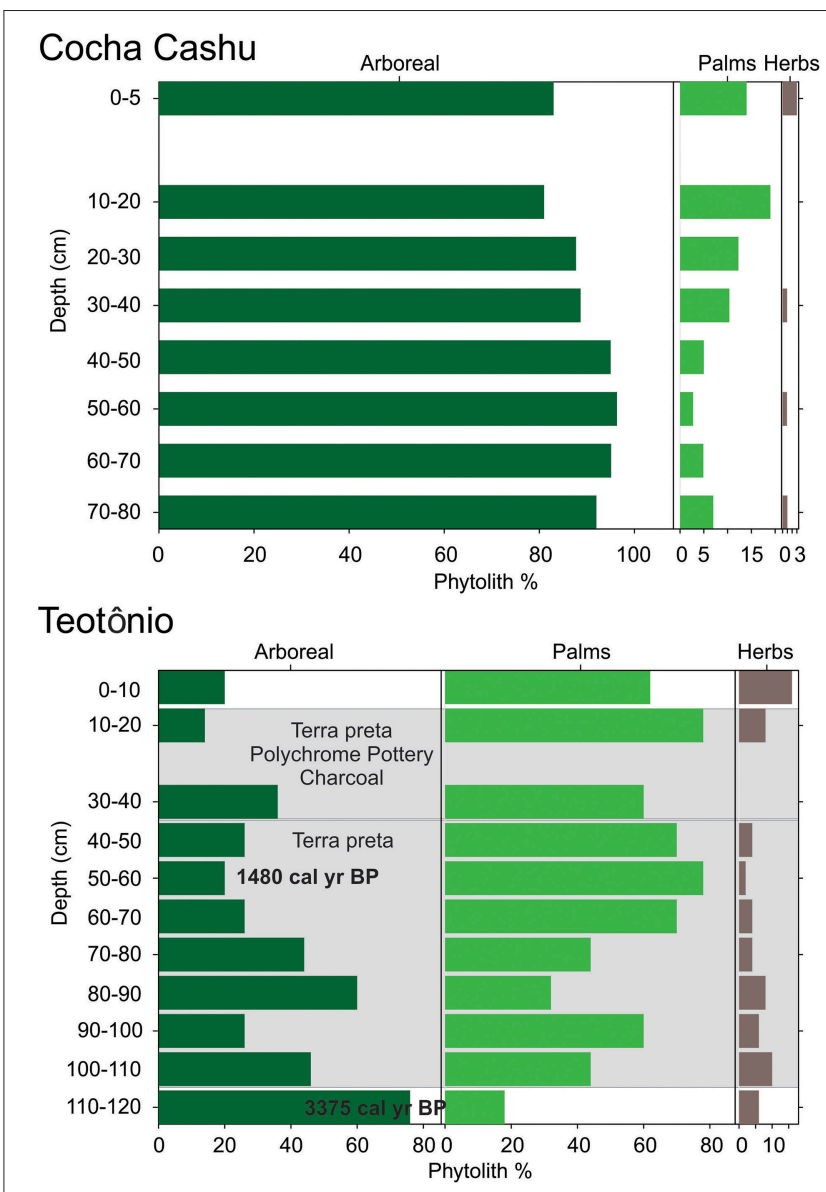

FIGURE 3 | Arboreal, palm, and herbaceous/early successional (herb) phytoliths from the Teotônio archeological site and the Cocha Cashu research station. The $x$-axis contains phytolith percentages, and the $y$-axis is core depth. ${ }^{14} \mathrm{C}$ AMS dates, descriptions of pottery, charcoal, and soil type are from Almeida and Neves (2014).

in the assemblage, and only reached $3 \%$ in the surface sample. The percentages of palm phytoliths were elevated in the upper $30 \mathrm{~cm}$ of the core, and reached a maximum percentage of $20 \%$, which was equal to the lowest value of palm percentages found in the basal layers of the Teotônio site (Figure 3). The trend values (trend = surface-basal percentage) of arboreal, palm, and herb phytolith types at Cocha Cashu were $-9,7$, and $2 \%$, respectively. The delta values (delta $=$ maximum-minimum percentage) for the arboreal, palm, and herb phytolith types were 15,16 , and $3 \%$, respectively.

A mixture of arboreal and palm phytoliths dominated the phytolith assemblage at Teotônio (Figure 3). Phytolith assemblages fluctuated drastically in the Teotônio soil profile, and at any given depth interval, the arboreal and palm phytolith percentages ranged from 20 to $80 \%$. Herbaceous (herb) phytoliths reached their maximum of $20 \%$ in the uppermost soil sample. Palms generally increased through time (going from the bottom of the core to the top) at the expense of other arboreal elements (Figure 3). The trend values (trend = surface-basal percentage) of arboreal, palm, and herb phytolith 
types at Teotônio were $-56,44$, and $10 \%$, respectively. The delta values (delta $=$ maximum-minimum percentage) for the arboreal, palm, and herb phytolith types were 62,60 , and $16 \%$, respectively. The levels of the Teotônio site that contained the highest amounts of palm phytoliths also contained large amounts of charcoal and pottery, and were located within the terra preta layers (Figure 3). Based on ${ }^{14} \mathrm{C}$ dating of the site (Almeida and Neves, 2014), palm increases occurred primarily after $1500 \mathrm{cal}$ year BP.

\section{Interregional Comparisons of Phytolith Assemblages}

The cores exhibited variability within cores, but the median arboreal phytolith percentages were above $80 \%$ in all regions except at the Teotonio archeological site, where percentages were markedly lower (Figure 4). The percentages of palm phytoliths were also higher in the Teotonio site compared with other regions (Figure 4). Much smaller, though noticeable, increases in palm phytolith percentages were also found in several samples at Lake Gentry, Lake Ayauchi, Rio Branco, and Tefé. Herb phytoliths were highly variable within some cores, including those examined from Teotônio and the lake sites (Figure 4).

The one-sample $t$-tests that compared the trends through time at Cocha Cashu with other regions revealed that the trends were significantly different for all phytolith types (arboreal, palm, and herbs) between Cocha Cashu and Iquitos (Table 2). The trends at Iquitos remained around zero for all phytolith types, whereas Cocha Cashu shifted a bit more through time toward increases in palms and herbs (Figure 5). It should be noted, however, that Iquitos had a small sample size $(n=3)$ compared with most of the other regions. The trends in increasing palms toward the surface of the core were also significantly higher in Cocha Cashu than at Lake Ayauch ${ }^{i}$ (Table 2, Figure 5). The trend of increasing herb taxa toward the surface of the core was also significantly higher for Cocha Cashu compared with Lake Gentry, which became more dominated by arboreal elements toward the tops of the cores (Table 2, Figure 5).

When the delta values from the Cocha Cashu core were compared with the other regions, several differences emerged (Table 3). The Cocha Cashu arboreal percentages fluctuated, i.e., had delta values, greater than the Porto Velho-Manaus (PVM), Iquitos, or Barcelos regions (Table 3, Figure 6). The delta value for the change in palm phytoliths was also significantly higher in Cocha Cashu than in Iquitos or Barcelos (Table 3, Figure 6). The delta value in herb phytoliths was significantly higher at Cocha Cashu compared with Iquitos, but was significantly lower than the delta values from Lakes Ayauch ${ }^{\mathrm{i}}$ and Gentry, and Tefe (Table 3, Figure 6).
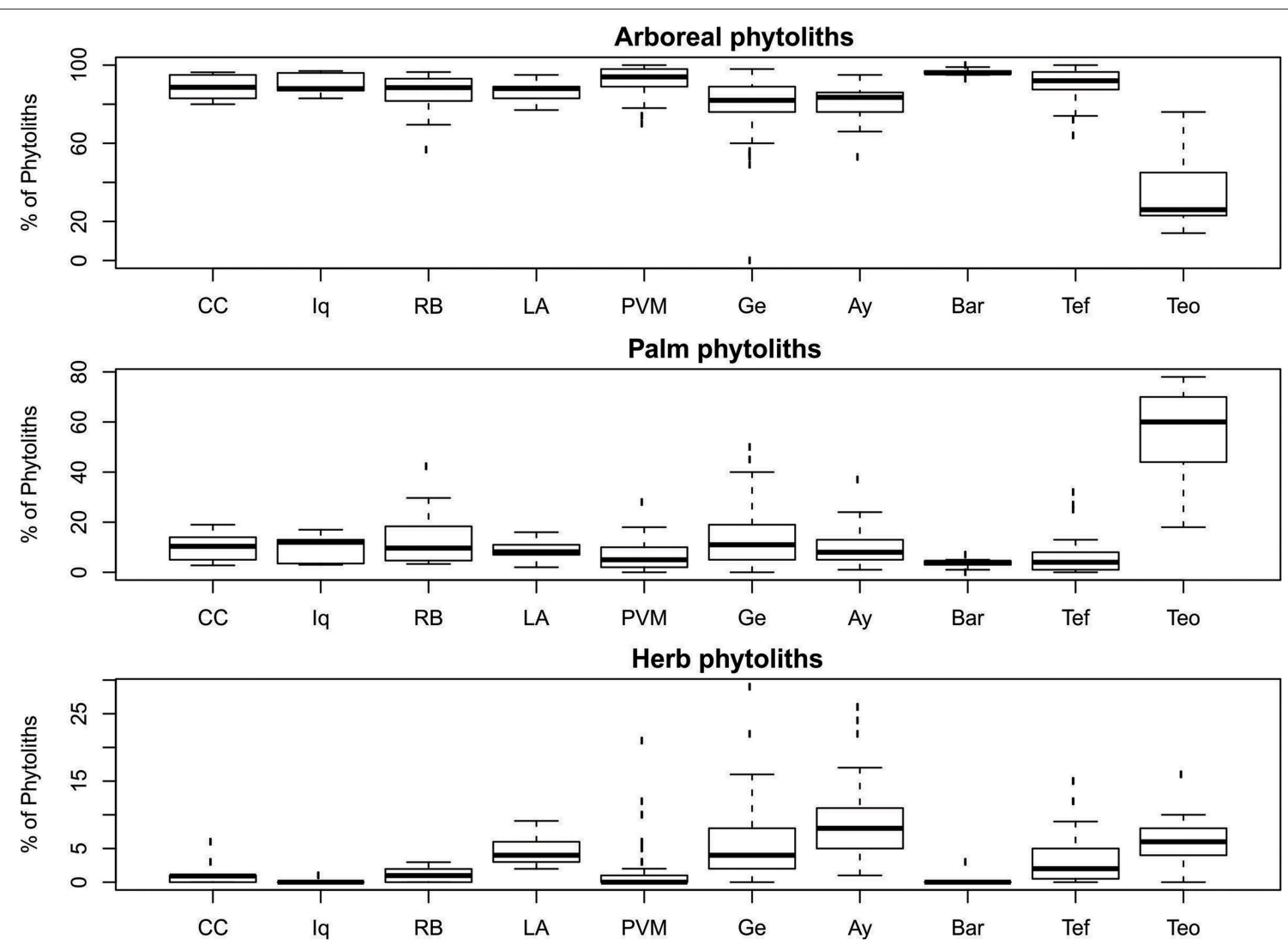

FIGURE 4 | Phytolith assemblages of total samples from each region surveyed. Region codes are as follows: Cocha Cashu (CC), Iquitos (Iq), Rio Branco (RB), Los Amigos (LA), Porto Velho-Manaus (PVM), Lake Gentry (Ge), Lake Ayauchi (Ay), Barcelos (Bar), Tefé (Tef), Teotônio (Teo). See Table 1 for total number of samples analyzed from each region. 
TABLE 2 | One-sample $t$-test results from regional comparisons of trend values (trend = surface-basal) of arboreal, herb and palm phytoliths with values obtained at Cocha Cashu and Teotônio.

\begin{tabular}{|c|c|c|c|c|c|c|c|c|c|}
\hline \multicolumn{2}{|c|}{ Regional trends } & \multicolumn{3}{|c|}{ Cocha Cashu } & \multirow[t]{2}{*}{$p^{\star}$ adj } & \multicolumn{3}{|c|}{ Teotônio } & \multirow[t]{2}{*}{$p^{\star}$ adj } \\
\hline Regions & Phytolith type & ts & $d f$ & $p$ & & ts & $d f$ & $p$ & \\
\hline PVM & arboreal & 1.22 & 14 & 0.24 & 0.48 & 24.50 & 14 & $7 \mathrm{E}-13$ & $1 \mathrm{E}-12$ \\
\hline Tefe & arboreal & 0.21 & 9 & 0.84 & 1.00 & 11.15 & 9 & 1E-06 & 3E-06 \\
\hline lquitos & arboreal & 8.00 & 2 & 0.02 & 0.03 & 55.00 & 2 & 3E-04 & 7E-04 \\
\hline Barcelos & arboreal & 5.20 & 2 & 0.04 & 0.07 & 45.90 & 2 & $5 E-04$ & 9E-04 \\
\hline Ayauchi & arboreal & -6.51 & 10 & 0.00 & 0.00 & -25.44 & 10 & $2 \mathrm{E}-10$ & 4E-10 \\
\hline Gentry & arboreal & -0.25 & 9 & 0.81 & 1.00 & -8.68 & 9 & 1E-05 & 2E-05 \\
\hline PVM & palm & -1.08 & 14 & 0.30 & 0.59 & -21.85 & 14 & $3 \mathrm{E}-12$ & $6 \mathrm{E}-12$ \\
\hline Tefe & palm & 0.27 & 9 & 0.79 & 1.00 & -9.68 & 9 & 5E-06 & 9E-06 \\
\hline Iquitos & palm & -6.43 & 2 & 0.02 & 0.05 & -48.38 & 2 & 4E-04 & 9E-04 \\
\hline Barcelos & palm & -3.46 & 2 & 0.07 & 0.15 & -35.51 & 2 & $8 \mathrm{E}-04$ & 2E-03 \\
\hline Ayauchi & palm & -6.51 & 10 & 0.00 & $<0.01$ & -25.44 & 10 & $2 \mathrm{E}-10$ & $4 \mathrm{E}-10$ \\
\hline Gentry & palm & -0.25 & 9 & 0.81 & 1.00 & -8.68 & 9 & 1E-05 & 2E-05 \\
\hline PVM & herb & -0.58 & 14 & 0.57 & 1.00 & -9.33 & 14 & $2 \mathrm{E}-07$ & 4E-07 \\
\hline Tefe & herb & -1.14 & 9 & 0.28 & 0.57 & -6.51 & 9 & 1E-04 & 2E-04 \\
\hline lquitos & herb & -7.00 & 2 & 0.02 & 0.04 & -31.00 & 2 & 1E-03 & 2E-03 \\
\hline Barcelos & herb & N/A & & & & $\mathrm{N} / \mathrm{A}$ & & & \\
\hline Ayauchi & herb & -1.15 & 10 & 0.28 & 0.56 & -6.45 & 10 & 7E-05 & 1E-04 \\
\hline Gentry & herb & -4.64 & 9 & 0.00 & $<0.01$ & -8.46 & 9 & 1E-05 & 3E-05 \\
\hline
\end{tabular}

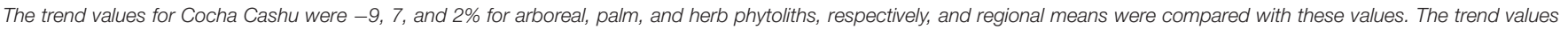

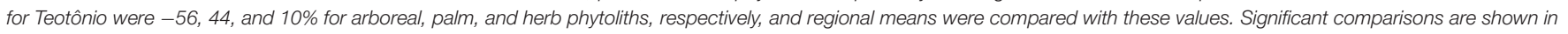
bold. ts, test statistic; $d f$, degrees of freedom; p, p-value; $p^{\star} a d j$, p-value adjusted with Bonferroni correction; PVM, Porto Velho-Manaus.

The one-sample $t$-tests that compared the regional phytolith trends through time (trend values) and magnitude of vegetation change (delta values) with Teotônio were significant for arboreal, palm, and herb phytoliths for all regions (Tables 2, 3). The trends toward increased palms and herbs toward the top of the core were significantly higher at than at Teotonio than at any other region surveyed (Figure 5). The increase in palms and herbs toward the top of the core at Teotonio came at the expense of arboreal taxa (Figure 5). The delta values were also significantly higher at Teotonio than in the other regions, clearly illustrating the direct and detectable effect of ancient people on vegetation (Figure 6).

\section{Regional "Human Impact" Scores}

Based on the collective archeological and palaeoecological evidence, the weighted human impact scores ranged from 635 (Teotônio) to 52 (Iquitos), with lower scores meaning less evidence of human impact and vegetation change (Table 4). The impact score of Cocha Cashu was 60, very similar to Iquitos. Impact scores for other regions ranged from 107 to 370, which were about double the scores found at Cocha Cashu or Iquitos, but yet half of the Teotonio score. The sites in close proximity to archeological sites (including Teotônio) and the lake sites had the highest impact scores. Other than at the two lake sites in western Amazonia, higher impact scores were found in central Amazonia compared with western Amazonia (Figure 7). Also, the higher impact scores correspond with areas predicted to have higher human impacts based on the locations of terras pretas, earthworks, and major archeological sites in Amazonia (Figure 7) (McMichael et al., 2014a,b).

\section{DISCUSSION}

\section{Relevance to Modern Ecology}

Most scholars loosely agree on the heterogeneity of the ancient human footprint in Amazonia (Heckenberger and Neves, 2009; McMichael et al., 2012a; Clement et al., 2015), and the data presented here confirm that some areas contained a more intensive ancient human footprint than others (Table 4, Figure 7). The distributions archeological evidence are not randomly distributed across the landscape, and areas that likely contained the majority of ancient human impacts in Amazonia are located along predictable environmental gradients (Figure 7; McMichael et al., 2014a,b). Terras pretas distributions are most closely associated with areas below $100 \mathrm{~m}$ elevation and on river bluffs located within $10 \mathrm{~km}$ of the Amazon River and its major tributaries (McMichael et al., 2014a). Teotônio fits this description, as it is located on a river bluff along the Upper Madeira River (Almeida and Neves, 2014). Earthwork construction in the region of Acre, Brazil was likely associated with proximity to the nearby ca. $165,000 \mathrm{~km}^{2}$ of bamboodominated forests (Guadua spp.; McMichael et al., 2014b). The predicted distributions of terras pretas and earthwork sites, alongside the locations of complex or hierarchically structured archeological sites, suggest that the majority of ancient human impacts occurred in the more seasonal areas of eastern and 

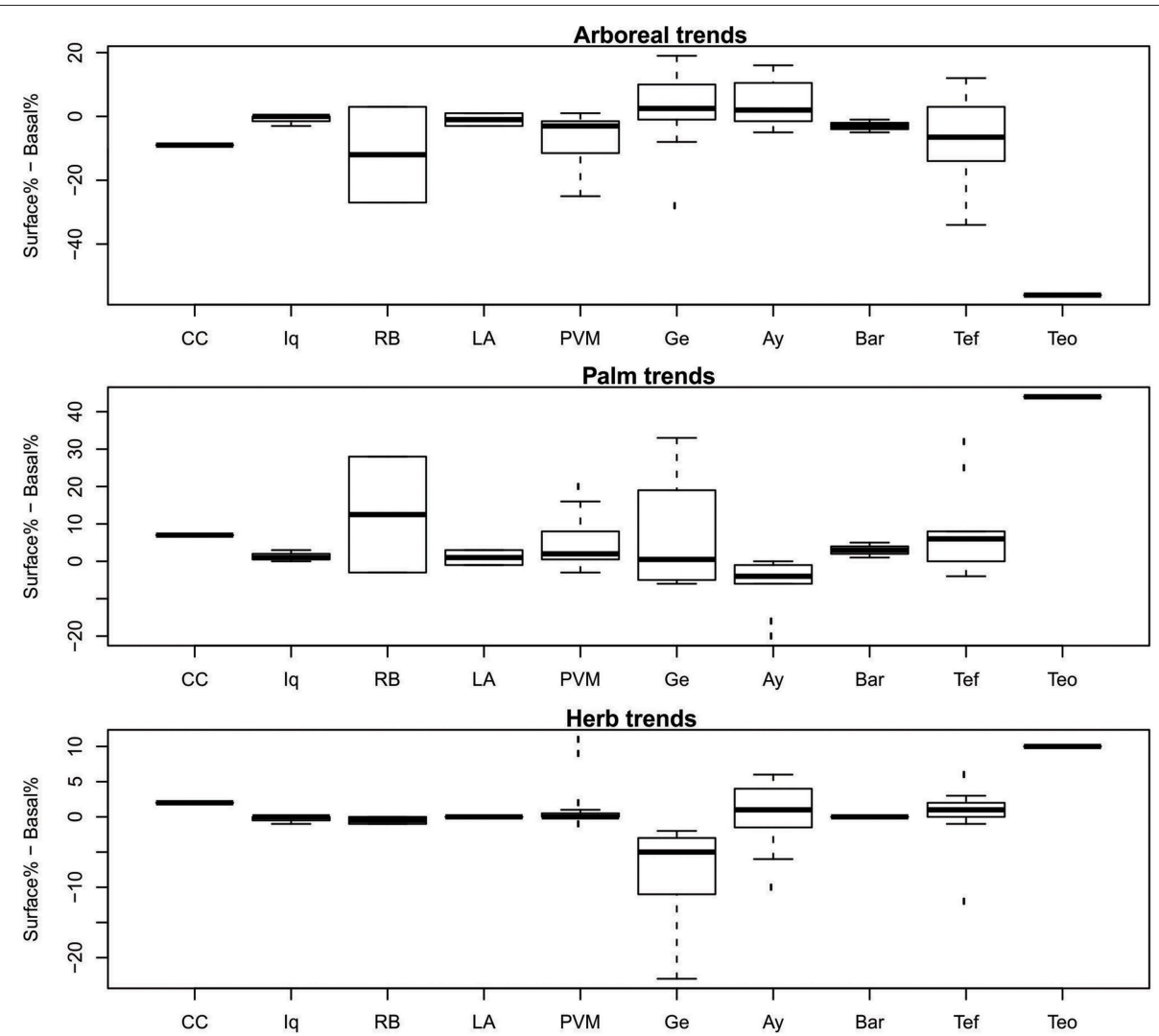

FIGURE 5 | Temporal trends from base to surface of the core. Positive values indicate an increase in those elements through time, negatives values indicate decreases. Regional codes are the same as listed in Figure 3. See Table $\mathbf{1}$ for total number of samples analyzed from each region.

southern Amazonia (Figure 7; Bush et al., 2015). Precipitation seasonality likely affected the distribution of ancient people on regional scales, and proximity to river seemed to drive their distributions within regions and on local scales (Denevan, 1996; Bush et al., 2015).

The seasonal regions of the Amazon, here considered those containing more than 3 months per year with $<100 \mathrm{~mm}$ precipitation, have a higher density of known settlement sites (McMichael et al., 2012a, 2014a; Neves, 2013). And within regions, the sphere of influence around occupied sites in the seasonal forests is seemingly greater than in the aseasonal areas. The soils sampled in Tefé, which is a seasonal region, were within $10 \mathrm{~km}$ of several known terra preta and archeological sites. The evidence of past fires and localized canopy openings were still visible at this distance. The opposite scenario was documented in the more aseasonal areas of Iquitos. Several soil samples were located within $10 \mathrm{~km}$ of the Quistococha archeological site, and they contained little evidence of fire and no evidence of impact on the vegetation in the phytolith records. Riverine bluff samples from Iquitos also showed little to no evidence of ancient human activity (McMichael et al., 2012a). These data suggest that localized distributions of ancient human occupation sites were also influenced by regional environmental characteristics.

The impact scores were in agreement with these models, except for the lake sites in the aseasonal portions of western
Amazonia, which contained higher impact scores than most of the regions surveyed (Table 4, Figure 7). Lake settings are also known to be preferable settlement locations, and about half of the lake sediment records from Amazonia contain evidence of human activity, though typically in temporally discontinuous patterns (Bush and Silman, 2007). Lake Ayauch ${ }^{\mathrm{i}}$, located in northwestern Amazonia, had the second-highest human impact score (Table 4, Figure 7). The lake is located on a river bluff at the base of the Andean flank, and has the oldest record of maize agriculture in Amazonia (Bush et al., 1989). But within a given watershed, some lakes will show evidence of ancient human activity (fire and agriculture) while others contain no charcoal and no evidence of people (Bush et al., 2007). These data confirm the anthropogenic nature of late-Holocene fire in Amazonian systems, and suggest that ancient population densities were not high enough that people occupied all suitable lakes.

The predicted and observed distribution of these ancient impacts (Figure 7) did not show any correspondence with Amazonian alpha-diversity patterns, which are highest in the aseasonal forests of northwestern Amazonia, and decrease going into the more seasonal forests of the east and south (Gentry, 1988; Silman, 2007). The northwestern forests of Iquitos actually contained little evidence of fire, and showed the smallest magnitude of vegetation change compared with any region surveyed (Figures 5, 6, Table 4). It is also located near the center 
TABLE 3 | One-sample $t$-test results from regional comparisons of delta values (delta = maximum-minimum) of arboreal, herb and palm phytoliths with values obtained at Cocha Cashu and Teotônio.

\begin{tabular}{|c|c|c|c|c|c|c|c|c|c|}
\hline \multicolumn{2}{|c|}{ Regional deltas } & \multicolumn{3}{|c|}{ Cocha Cashu } & \multirow[t]{2}{*}{$p^{\star}$ adj } & \multicolumn{3}{|c|}{ Teotonio } & \multirow[t]{2}{*}{$p^{\star}$ adj } \\
\hline Regions & Phytolith type & ts & $d f$ & $p$ & & ts & $d f$ & $p$ & \\
\hline PVM & Arboreal & -3.24 & 14 & 0.01 & 0.01 & -27.81 & 14 & $1 \mathrm{E}-13$ & $2 E-13$ \\
\hline Tefe & Arboreal & 0.23 & 9 & 0.82 & 1.00 & -15.34 & 9 & 9E-08 & 2E-07 \\
\hline lquitos & Arboreal & -15.50 & 2 & 0.00 & 0.01 & -68.79 & 2 & $2 \mathrm{E}-04$ & 4E-04 \\
\hline Barcelos & Arboreal & -6.43 & 2 & 0.02 & 0.05 & -33.07 & 2 & 9E-04 & 2E-03 \\
\hline Ayauchi & Arboreal & -1.62 & 10 & 0.14 & 0.27 & -16.15 & 10 & 2E-08 & 3E-08 \\
\hline Gentry & Arboreal & 0.16 & 9 & 0.88 & 1.00 & -13.57 & 9 & 3E-07 & $5 \mathrm{E}-07$ \\
\hline PVM & Palm & -4.83 & 14 & 0.00 & $<0.01$ & -31.61 & 14 & $2 \mathrm{E}-14$ & 4E-14 \\
\hline Tefe & Palm & -1.49 & 9 & 0.17 & 0.34 & -16.04 & 9 & 6E-08 & 1E-07 \\
\hline Iquitos & Palm & -16.63 & 2 & 0.00 & 0.01 & -66.52 & 2 & 2E-04 & $5 \mathrm{E}-04$ \\
\hline Barcelos & Palm & -7.86 & 2 & 0.02 & 0.03 & -36.66 & 2 & 7E-04 & 1E-03 \\
\hline Ayauchi & Palm & -1.62 & 10 & 0.14 & 0.27 & -16.15 & 10 & $2 \mathrm{E}-08$ & 3E-08 \\
\hline Gentry & Palm & 0.16 & 9 & 0.88 & 1.00 & -13.57 & 9 & 3E-07 & $5 E-07$ \\
\hline PVM & Herb & 0.09 & 14 & 0.93 & 1.00 & -8.95 & 14 & 4E-07 & 7E-07 \\
\hline Tefe & Herb & 3.72 & 9 & 0.00 & 0.01 & -6.36 & 9 & 1E-04 & 3E-04 \\
\hline Iquitos & Herb & -8.00 & 2 & 0.02 & 0.03 & -47.00 & 2 & 5E-04 & $9 \mathrm{E}-04$ \\
\hline Barcelos & Herb & -2.00 & 2 & 0.18 & 0.37 & -15.00 & 2 & $4 \mathrm{E}-03$ & 9E-03 \\
\hline Ayauchi & Herb & 4.40 & 10 & 0.00 & $<0.01$ & -3.37 & 10 & 7E-03 & 1E-02 \\
\hline Gentry & Herb & 3.26 & 9 & 0.01 & 0.02 & -2.32 & 9 & 5E-02 & 9E-02 \\
\hline
\end{tabular}

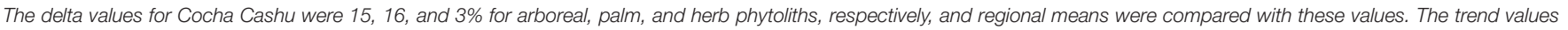

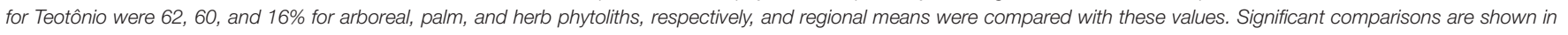
bold. ts, test statistic; $d f$, degrees of freedom; $p, p$ value; $p^{*}$ adj, $p$-value adjusted with Bonferroni correction; PVM, Porto Velho-Manaus.

of Amazonian biodiversity. Overall, empirical data suggests that Amazonian diversity is higher in areas that were much less likely to have contained a strong footprint of ancient people.

Further, our data support the view that the hyper-diverse forests of Cocha Cashu are some of the most undisturbed forests remaining in the Amazon (Terborgh, 1990). It would be interesting to perform proper archeological surveys in this region to further test this hypothesis. A nearby research station, Los Amigos (also known as CICRA), is in the same climatic zone as Cocha Cashu. But almost half the cores from Los Amigos contained evidence of fire, and only six cores from Cocha Cashu ( $16 \%$ of total) contained charcoal (Table 4). Though we did not have enough replicate cores at Los Amigos to test for significant differences in vegetation change through time with Cocha Cashu, the trend and delta values for Los Amigos suggested little vegetation change and showed similar patterns to Cocha Cashu and Iquitos (Figures 5, 6). Artifacts have been recovered from a streambed at Los Amigos and were on display at the research station (Pitman, N., personal communication). Though undated, the presence of artifacts supports charcoal data and phytolith data that suggested low-impact and localized ancient human activity occurred in the Los Amigos region primarily from 3000 to 1000 years ago (McMichael et al., 2012a,c).

The Los Amigos and Cocha Cashu research stations provide an excellent opportunity for comparing tree plot data with modern and prehistoric phytolith signatures to examine the successional trajectories of tropical forests under different ancient disturbance regimes. Most ecological study sites (i.e., tree plots) are located in areas that are not known to contain archeological features or modified terra preta soils (Quesada et al., 2011). The actual human history of those sites, however, is largely unknown because there have been no proper archeological or paleoecological surveys. Performing charcoal and phytolith analyses on soils from ecological research stations and deriving human impact scores, such as those presented here, would provide a longer-term history of vegetation change in locations where modern ecological dynamics are currently being studied on shorter timescales. The integration of paleoecological and archeological approaches (Mayle and Iriarte, 2014) into a modern ecological context can provide additional factors to explain variance in the observed processes and patterns in Amazonian forests.

A suite of 227 species, termed hyperdominant species, accounted for approximately half of all the individual trees inventoried across 1170 Amazonian tree plots (ter Steege et al., 2013). One hypothesis for this pattern is that ancient people cultivated and promoted particular species in the areas that they inhabited. Arecaceae, the palm family, was the second most common family of plants documented in this survey of over 1400 tree plots in Amazonia, and 15 species of palm were considered hyperdominants (ter Steege et al., 2013). Palms are also some of the most economically important species in Amazonia (e.g., Clement, 1988, 2006; Rull and Montoya, 2014). An interesting and valuable avenue for future research will be to determine to what extent the modern Amazonian palm distributions have resulted from human manipulation, as was seen at Teotônio 

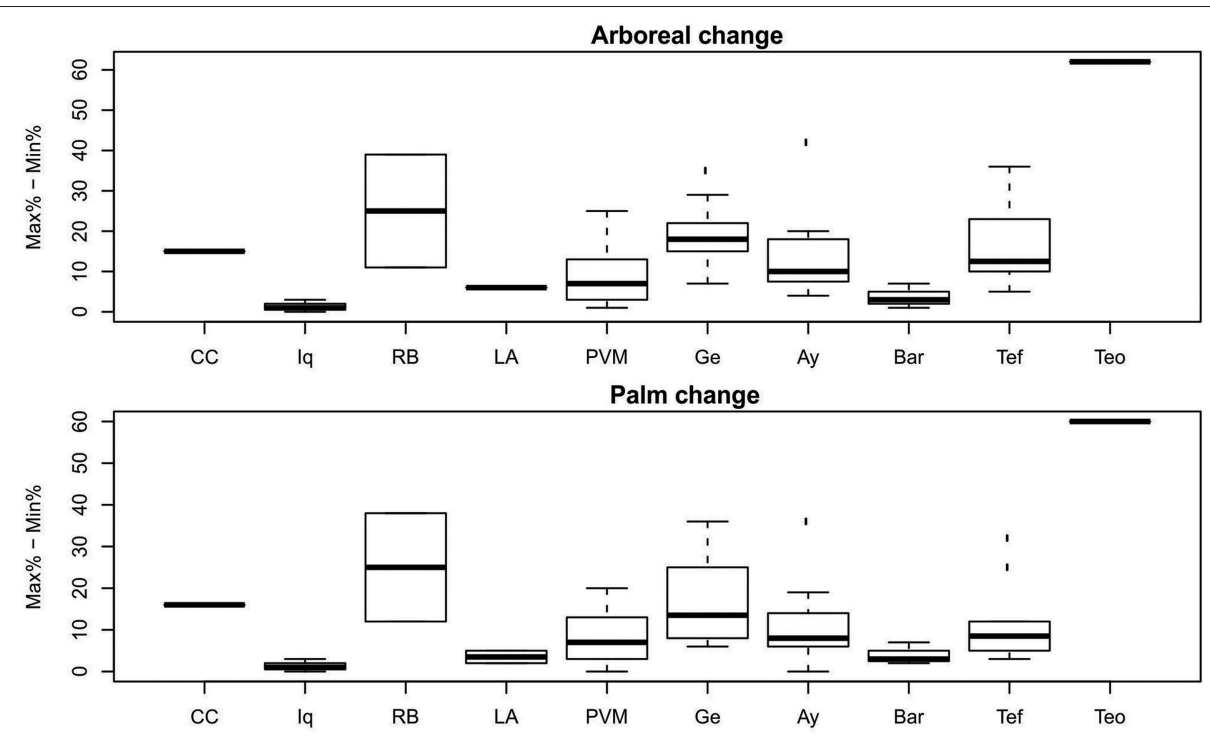

Herb change

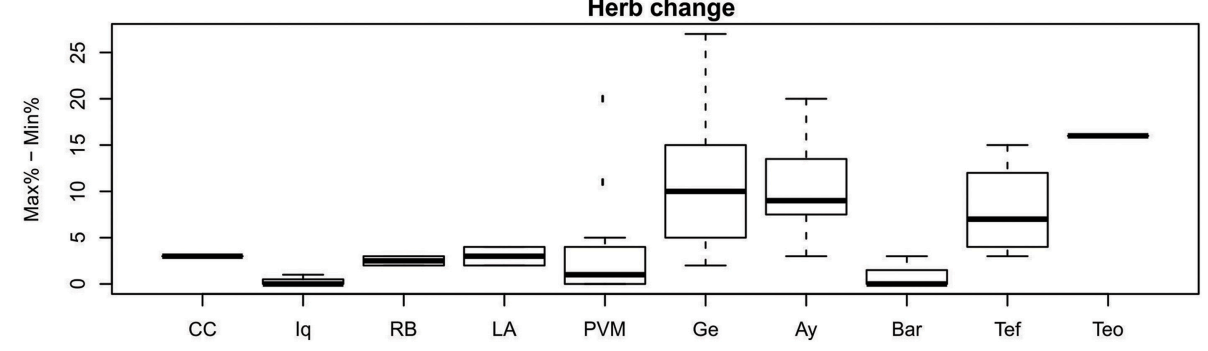

FIGURE 6 | Magnitude of change in phytolith percentages within a core. Regional codes are the same as listed in Figure $\mathbf{3}$. See Table $\mathbf{1}$ for total number of samples analyzed from each region.

(Figures 4-6). Though as the Cocha Cashu data have shown, changes in palm abundances through time can occur at sites that so far contain very little evidence for past human activity (Figures 4-6). Thus, the even broader question remains as to whether the suite of hyperdominants is a stable feature of the landscape, or if decadal-scale ecological observations are just a fleeting glimpse into a dynamic system with high rates of ecological turnover, albeit natural or anthropogenic, through time.

\section{Quantifying a Gradient of Ancient Disturbance}

The phytolith analyses, including the metrics used to assess within-region and between-region variability, were sufficiently sensitive to detect changes in forest composition, both in the presence and likely absence of human activity (Figures 3-6). The detection ability documented in this study suggests that phytolith analysis of soils can accurately reconstruct forest stability or dynamism across space, and through time when material is dated. These results demonstrate an avenue to directly relate prehistoric disturbances, or disturbances from the historical period, with modern observations of forest composition. The lack of this linkage was a limitation in previous work that associated modern
Amazonian flora with pre-Columbian human activity (Levis et al., 2012).

The data presented here also identify regions that can be considered baselines from which to measure ancient disturbance, which recent reviews claiming that the majority of Amazonia was domesticated failed to do (Clement et al., 2015). Palms are well known to be important sources of food and building material for indigenous and local people (Clement, 1988, 2006; Sosnowska et al., 2015). Increased densities of both useful and non-useful palm species have been reported at other archeological sites, especially those containing terra pretas (Fraser and Clement, 2008; Fraser et al., 2011; Junqueira et al., 2011). The lasting signature of ancient palm enrichment that has occurred over the last 1500 years was clearly documented in the phytolith assemblages from Teotônio (Figure 3), providing a baseline to compare with other regions of unknown human history. Though palms tended to increase from the bottom to the top of the core in several regions, it was never at the magnitude recorded at Teotônio (Figure 5). Anthropogenic influence has also been proposed for increased palm densities in the Gran Sabana region of Venezuela (Rull and Montoya, 2014). Patterns of Brazil nut (Bertholletia excelsa) distribution and abundance have also been linked to ancient human activity and proximity to terras pretas (Shepard and Ramirez, 2011; Thomas et al., 2015). 
TABLE 4 | Human impact scores calculated from regions included in Figure 1.

\begin{tabular}{|c|c|c|c|c|c|c|c|c|c|c|c|c|c|c|c|}
\hline Location & Code & Cores & TP & W(TP) & $\mathrm{Ag}$ & W(Ag) & $\%$ Char & W(Ch) & dESH & W(dESH) & $\mathrm{dP}$ & $W(d P)$ & tAR & W(tAr) & Impact score \\
\hline Teotonio & Teo & 1 & 1 & 3 & 100 & 3 & 100 & 2 & 16 & 1 & 60 & 1 & 56 & 1 & 635 \\
\hline Ayauchi & Ay & 11 & 0 & 3 & 55 & 3 & 67 & 2 & 20 & 1 & 36 & 1 & 16 & 1 & 370 \\
\hline Gentry & $G$ & 10 & 0 & 3 & 10 & 3 & 63 & 2 & 27 & 1 & 36 & 1 & 28 & 1 & 248 \\
\hline Tefe & $\mathrm{T}$ & 10 & 1 & 3 & 0 & 3 & 75 & 2 & 15 & 1 & 32 & 1 & 34 & 1 & 234 \\
\hline Porto Velho-Manaus & PV-M & 16 & 0 & 3 & 6 & 3 & 62 & 2 & 20 & 1 & 20 & 1 & 25 & 1 & 206 \\
\hline Barcelos & $B$ & 3 & 1 & 3 & 0 & 3 & 90 & 2 & 3 & 1 & 7 & 1 & 5 & 1 & 199 \\
\hline Rio Branco & $\mathrm{RB}$ & 2 & 0 & 3 & 0 & 3 & 50 & 2 & 3 & 1 & 38 & 1 & 27 & 1 & 168 \\
\hline Los Amigos & $\llcorner A$ & 3 & 0 & 3 & 0 & 3 & 47 & 2 & 4 & 1 & 5 & 1 & 3 & 1 & 107 \\
\hline Iquitos & lq & 3 & 0 & 3 & 0 & 3 & 23 & 2 & 1 & 1 & 3 & 1 & 3 & 1 & 52 \\
\hline Cocha Cashu & $\mathrm{CC}$ & 1 & 0 & 3 & 0 & 3 & 16 & 2 & 3 & 1 & 16 & 1 & 9 & 1 & 60 \\
\hline
\end{tabular}

Impact scores were calculated based on TP (presence/absence of terra preta) and its weighting $\left(W_{(T P)}\right)$, Ag (percentage of sites with evidence of agriculture) and its weighting $\left.\mathrm{W}_{\text {(Ag) }}\right]$, the percentage of cores that contained charcoal $(\% \mathrm{Ch})$ and its weighting $\left[W_{(\mathrm{Ch})}\right]$, magnitude of change of herb $(d E S H)$ and palm $(d P)$ phytoliths and their weightings $\left[W_{(d E S H)}\right.$ and $\left.W_{(d P)}\right]$, and magnitude of overall change of arboreal phytoliths and its weighting $\left[W_{(t A R)}\right]$. The sums of the weighted values were used to calculate the Impact Score.

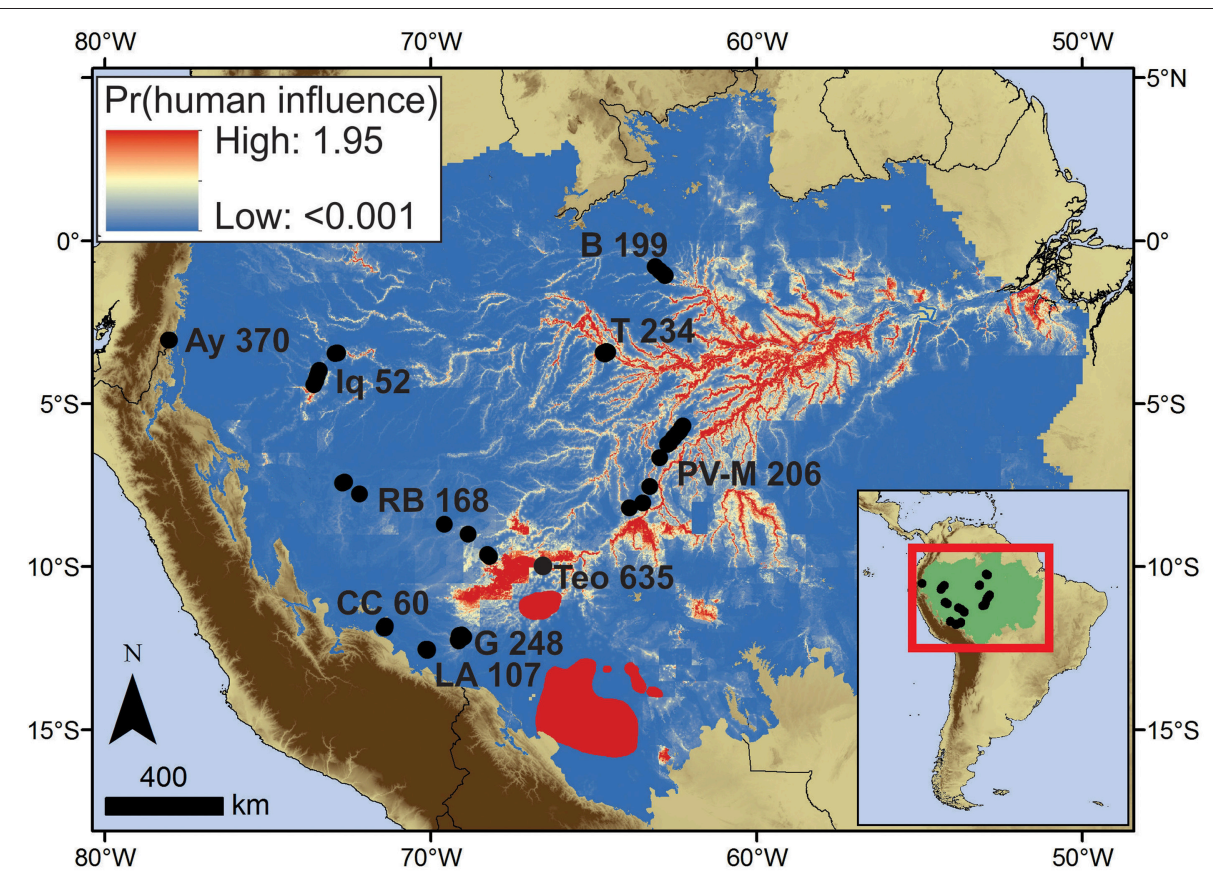

FIGURE 7 | Summed probabilities of predictive models of terras pretas (McMichael et al., 2014a), geoglyphs (McMichael et al., 2014b), and major archeological sites (Roosevelt et al., 1991, 1996; Erickson, 2006; Heckenberger et al., 2008) within Amazonia sensu stricto. The highest probabilities indicate where anthropogenic influence on past, and potentially present, vegetation is most likely based on available data. It is worth noting, however, that additional unreported data on archeology that could be used to refine this model within regions of Amazonia, and extend the predictions into the regions surrounding Amazonia.

It must be noted, however, that an observed high density of Brazil nut, or Arecaceae (palms) does not necessarily imply ancient human manipulation. The Cocha Cashu phytolith assemblages establish a first measurement of the variability of palms through time where ancient human impact appears to be much lower than in the other regions surveyed (Table 4). Though we cannot say that humans never inhabited the Cocha Cashu landscape, we can say that it has not experienced frequent or recurrent fire, contained no evidence for significant vegetational modifications, terra pretas, or artifacts in the soil surveys conducted across the site, and varied in the palm and arboreal phytolith percentages by $20 \%$. The trends of increasing abundances and variances of palms in Cocha Cashu and the other surveyed regions that contained similar variability, cannot be attributed to a specific cause. While humans may have played a role in palm increases in those regions, the overall absence of associated evidence for significant vegetation modification by humans at the sites studied suggest it was not outside the scope of natural variation or Holocene climate change.

All other regions that were sampled exhibited a lesser human signature than Teotonio, but more evidence of human activity than Cocha Cashu and Iquitos. These lightly- to 
moderately-impacted regions contained evidence of past fires and/or evidence of localized agriculture. A clear and expected trend in the vegetation response was the increase of herb phytoliths in areas containing more evidence of fire (Figures 4-6, Table 4). Herb phytoliths were rare to nonexistent in the Cocha Cashu and Iquitos samples, which also contained little to no fire in the regional charcoal surveys.

Soil data from around Lakes Ayauch ${ }^{\mathrm{i}}$ (Ecuador) and Gentry (Peru) contained trends toward more forested systems in modern times (i.e., signals of localized ancient forest clearing), and localized increases in herb and palm phytoliths (Figures 3-5). These soil data have corresponding lake sediment archives that provided temporal control and additional documentation of human activity and vegetation change (Bush et al., 1989, 2007; McMichael et al., 2012b). These lake records and soil records contained evidence of localized fire and maize cultivation primarily between 2500 and 1000 cal year BP (McMichael et al., 2012b), and the Lake Ayauch ${ }^{\mathrm{i}}$ record contained the oldest evidence of maize cultivation documented in Amazonia at $\sim 6000$ cal year BP (Bush et al., 1989). Though both sites contained relatively similar percentages of cores containing charcoal, maize phytoliths were found in six cores at Lake Ayauch ${ }^{\mathrm{i}}$, and in only one at Lake Gentry (McMichael et al., 2012b).

Signatures of human activity in paleoecological records, including the presence or absence of charcoal, presence or

\section{REFERENCES}

Aldrich, S. P., and WinklerPrins, A. M. G. A. (2010). Locating amazonian dark earths: creating an interactive GIS of known locations. J. Lat. Am. Geogr. 9, 33-50. doi: 10.1353/lag.2010.0029

Almeida, F. O., and Neves, E. G. (2014). "The polychrome tradition at the upper Madeira river," in Antes de Orellana, Actas del 3rd Encuentro Internacional de Arqueologia Amazonica, ed S. Rostain (Lima: Instituto Francés de Estudios Andinos), 175-182.

Balée, W. (1988). Indigenous adaptation to Amazonian palm forests. Principes 32, 47-54.

Balée, W. (1989). “The culture of Amazonian forests," in Resource Management in Amazonia: Indigenous and Folk Strategies, eds D. A. Posey and W. Balée (New York, NY: New York Botanical Garden), 1-21.

Balée, W. (1993). Indigenous transformation of Amazonian forests: an example from Maranhao, Brazil. Homme 33, 231-254. doi: 10.3406/hom.1993.369639

Balée, W. (2010). Contingent diversity on Anthropic landscapes. Diversity 2, 163-181. doi: 10.3390/d2020163

Balée, W. (2014). "Historical ecology and the explanation of diversity: Amazonian case studies," in Applied Ecology and Human Dimensions in Biological Conservation, eds L. M. Verdade, M. C. Lyra-Jorge, and C. I. Piña (Berlin: Springer), 19-33.

Bush, M. B., McMichael, C. H., Piperno, D. R., Silman, M. R., Barlow, J. B., Peres, C. A., et al. (2015). Anthropogenic influence on Amazonian forests in prehistory: an ecological perspective. J. Biogeogr. 42, 2277-2288. doi: 10.1111/jbi.12638

Bush, M. B., Piperno, D. R., and Colinvaux, P. A. (1989). A 6000 year history of Amazonian maize cultivation. Nature 340, 303-305. doi: 10.1038/340303a0

Bush, M. B., and Silman, M. R. (2007). Amazonian exploitation revisited: ecological asymmetry and the policy pendulum. Front. Ecol. Environ. 5, 457-465. doi: 10.1890/070018

Bush, M. B., Silman, M. R., de Toledo, M. B., Listopad, C., Gosling, W. D., Williams, C., et al. (2007). Holocene fire and occupation in Amazonia: Records from two lake districts. Philos. Trans. R. Soc. Lond. B Biol. Sci. 362, 209-218. doi: $10.1098 /$ rstb.2006.1980 absence of agricultural microfossils, presence or absence of ceramics, lithics, and other cultural artifacts, and presence or absence of terra preta soils, can all be assessed alongside phytolith assemblages to provide a robust reconstruction of effects of ancient humans on the vegetation. Here we have provided a method to quantify those effects across regions and with dealing with unequal sample numbers. Multi-proxy approaches are required to continue unraveling the effects of both ancient and modern humans on Amazonian landscapes.

\section{AUTHOR CONTRIBUTIONS}

CM conceived the idea, collected the soil cores, contributed to the phytolith analysis, and wrote the manuscript. DP conceived the idea, and performed the majority of the phytolith analyses. EN conceived the idea and performed the archeological surveys MB conceived the idea. FA and GM performed the archeological excavations. ME performed the charcoal analyses.

\section{ACKNOWLEDGMENTS}

We would like to thank NSF DEB 0742301. This is publication \#129 from the Climate Change Institute at Florida Institute of Technology.
Bush, M. B., Silman, M. R., McMichael, C., and Saatchi, S. (2008). Fire, climate change and biodiversity in Amazonia: a Late-Holocene perspective. Philos. Trans. R. Soc. B Biol. Sci. 363, 1795-1802. doi: 10.1098/rstb.2007.0014

Carcaillet, C. (2001). Are Holocene wood-charcoal fragments stratified in alpine and subalpine soils? Evidence from the Alps based on AMS 14C dates. Holocene 11, 231. doi: 10.1191/095968301674071040

Carcaillet, C., and Talon, B. (1996). Stratigraphie et datations de charbons de bois dans les Alpes: quelques aspects taphonomiques. Geogr. Phys. Q. 50, 233-244. doi: 10.7202/033091ar

Carcaillet, C., and Thinon, M. (1996). Pedoanthracological contribution to the study of the evolution of the upper treeline in the Maurienne Valley (North French Alps): methodology and preliminary data. Rev. Palaeobot. Palynol. 91, 399-416. doi: 10.1016/0034-6667(95)00060-7

Clark, D. B. (1996). Abolishing virginity. J. Trop. Ecol. 12, 735-739. doi: 10.1017/S0266467400009937

Clark, D. B., Palmer, M. W., and Clark, D. A. (1999). Edaphic factors and the landscape-scale distributions of tropical rain forest trees. Ecology 80, 2662-2675. doi: 10.1890/0012-9658(1999)080[2662:EFATLS]2.0.CO;2

Clark, J. S., and Patterson, W. A. (1997). "Background and local charcoal in sediments: scales of fire evidence in the paleorecord," in Sediment Records of Biomass Burning and Global Change, eds J. S. Clark, H. Cachier, J. G. Goldammer, and B. Stocks (Berlin: Springer), 23-48. doi: 10.1007/978-3-64259171-6_3

Clement, C. R. (1988). Domestication of the pejibaye palm (Bactris gasipaes): past and present. Adv. Econ. Bot. 6, 155-174.

Clement, C. R. (2006). "Fruit trees and the transition to food production in Amazonia," in Time and Complexity in Historical Ecology: Studies in the Neotropical Lowlands, eds W. Balee and C. L. Erickson (New York, NY: Columbia University Press), 165-186.

Clement, C. R., de Cristo-Araújo, M., d'Eeckenbrugge, G. C., Alves Pereira, A., and Picanço-Rodrigues, D. (2010). Origin and domestication of native Amazonian crops. Diversity 2, 72-106. doi: 10.3390/d2010072

Clement, C. R., Denevan, W. M., Heckenberger, M. J., Junqueira, A. B., Neves, E. G., Teixeira, W. G., et al. (2015). The domestication of Amazonia before 
European conquest. Proc. R. Soc. B Biol. Sci. 282:20150813. doi: 10.1098/rspb.20 15.0813

Colinvaux, P. A., de Oliveira, P. E., and Moreno, J. E. (1999). Amazon Pollen Manual and Atlas. New York, NY: Hardwood Academic Press.

da Silva, A. D., and Pinheiro, E. S. (2010). A problemática dos resíduos sólidos urbanos em Tefé, Amazonas/The issue of urban solid waste in Tefé, Amazonas State, Brazil. Revista Soc. Nat. 22, 297-312. doi: 10.1590/S198245132010000200006

da Silva, A. L. (2008). Animais medicinais: conhecimento e uso entre as populações ribeirinhas do rio Negro, Amazonas, Brasil. Boletim Museu Paraense Emílio Goeldi Ciências Humanas 3, 343-357. doi: 10.1590/S1981-81222008000300005

de Freitas, H. A., Pessenda, L. C. R., Aravena, R., Gouveia, S. E. M., de Souza Ribeiro, A., and Boulet, R. (2001). Late Quaternary vegetation dynamics in the southern Amazon basin inferred from carbon isotopes in soil organic matter. Q. Res. 55, 39-46. doi: 10.1006/qres.2000.2192

Denevan, W. M. (1996). A bluff model of riverine settlement in prehistoric Amazonia. Ann. Assoc. Am. Geogr. 86, 654-681. doi: 10.1111/j.14678306.1996.tb01771.x

Elton, C. S. (1927). Animal Ecology. Chicago, IL: University of Chicago Press.

Erickson, C. L. (2000). An artificial landscape-scale fishery in the Bolivian Amazon. Nature 408, 190-193. doi: 10.1038/35041555

Erickson, C. L. (2006). “The domesticated landscapes of the Bolivian Amazon," in Time and complexity in historical ecology: studies in the neotropical lowlands, eds W. Balée and C. L. Erickson (New York, NY: Columbia University Press), 235-278.

Fearnside, P. M., and de Alencastro Graça, P. M. L. (2009). BR-319: A rodovia Manaus-Porto Velho eo impacto potencial de conectar o arco de desmatamento à Amazônia Central. Novos Cadernos NAEA 12, 19-50. doi: $10.5801 / \mathrm{ncn} . v 12 \mathrm{i} 1.241$

Fonseca Duarte, A. (2006). Aspectos da climatologia do Acre, Brasil, com base no intervalo 1971-2000. Revista Brasileira de Meteorol. 21, 308-317.

Foster, R. (1990). “The floristic composition of the Rio Manu floodplain forest," in Four Neotropical Rainforests, ed A. H. Gentry (New Haven, CT: Yale University Press), 99-111.

Francis, J. K., and Knowles, O. H. (2001). Age of A2 horizon charcoal and forest structure near Porto Trombetas, Pará, Brazil. Biotropica 33, 385-392. doi: 10.1111/j.1744-7429.2001.tb00193.x

Fraser, J. A., and Clement, C. R. (2008). Dark Earths and manioc cultivation in Central Amazonia: a window on pre-Columbian agricultural systems? Boletim do Museu Paraense Emílio Goeldi. Ciências Humanas 3, 175-194. doi: 10.1590/S1981-81222008000200004

Fraser, J., Junqueira, A., Kawa, N., Moraes, C., and Clement, C. (2011). Crop Diversity on Anthropogenic Dark Earths in Central Amazonia. Hum. Ecol. 39, 395-406. doi: 10.1007/s10745-011-9405-z

Gentry, A. H. (1988). Changes in plant community diversity and floristic composition on environmental and geographical gradients. Ann. Mo. Bot. Gard. 75, 1-34. doi: 10.2307/2399464

Gentry, A., and Terborgh, J. (1990). "Composition and dynamics of the Cocha Cashu mature floodplain forest," in Four Neotropical Rainforests, ed A. H. Gentry (New Haven, CT: Yale University Press), 542-564.

Hartshorn, G. S. (1978). “Tree falls and tropical forest dynamics," in Tropical Trees as Living Systems, eds P. B. Tomlinson and M. H. Zimmerman (Cambridge: Cambridge University Press), 617-638.

Heckenberger, M. J., Kuikuro, A., Kuikuro, U. T., Russell, J. C., Schmidt, M., Fausto, C., et al. (2003). Amazonia 1492: Pristine forest or cultural parkland? Science 301, 1710-1714. doi: 10.1126/science.1086112

Heckenberger, M., and Neves, E. G. (2009). Amazonian archaeology. Annu. Rev. Anthropol. 38, 251-266. doi: 10.1146/annurev-anthro-091908-164310

Heckenberger, M. J., Russell, J. C., Fausto, C., Toney, J. R., Schmidt, M. J., Pereira, E., et al. (2008). Pre-Columbian urbanism, anthropogenic landscapes, and the future of the Amazon. Science 321, 1214-1217. doi: 10.1126/science.11 59769

Hubbell, S. P. (2001). The Unified Neutral Theory of Biodiversity and Biogeography. Princeton, NJ: Princeton University Press.

Hutchinson, G. E. (1957). Concluding Remarks. Cold Spring Harb. Symp. Quant. Biol. 22, 415-427. doi: 10.1101/SQB.1957.022.01.039

Junqueira, A. B., Shepard, G. H., and Clement, C. R. (2011). Secondary forests on Anthropogenic soils of the middle Madeira River: valuation, local knowledge, and landscape domestication in Brazilian Amazonia. Econ. Bot. 1-15. doi: 10.1007/s12231-010-9138-8

Levis, C., de Souza, P. F., Schietti, J., Emilio, T., da Veiga Pinto, J. L. P., Clement, C. R., et al. (2012). Historical human footprint on modern tree species composition in the Purus-Madeira interfluve, central Amazonia. PLoS ONE 7:e48559. doi: 10.1371/journal.pone.0048559

Listopad, C. (2001). Vegetational Changes, Fire History and Human Impact during the Last 6000 Years: A Paleoecological Study of the Madre De Dios Province, Lowland Peru. MS, Florida Institute of Technology.

Lombardo, U., Szabo, K., Capriles, J. M., May, J.-H., Amelung, W., Hutterer, R., et al. (2013). Early and middle Holocene Hunter-Gatherer occupations in Western Amazonia: The hidden shell middens. PLoS ONE 8:e72746. doi: 10.1371/journal.pone.0072746

Marlon, J., Bartlein, P., Carcaillet, C., Gavin, D., Harrison, S., Higuera, P., et al. (2008). Climate and human influences on global biomass burning over the past two millennia. Nat. Geosci. 1, 697-702. doi: 10.1038/ngeo313

Mayle, F. E., and Iriarte, J. (2014). Integrated palaeoecology and archaeology-A powerful approach for understanding pre-Columbian Amazonia. J. Archaeol. Sci. 51, 54-64. doi: 10.1016/j.jas.2012.08.038

McMichael, C. H., Bush, M. B., Piperno, D. R., Silman, M. R., Zimmerman, A. R., and Anderson, C. (2012b). Spatial and temporal scales of pre-Columbian disturbance associated with western Amazonian lakes. Holocene 22, 131-141. doi: 10.1177/0959683611414932

McMichael, C. H., Bush, M. B., Silman, M. R., Piperno, D. R., Raczka, M., Lobato, L. C., et al. (2013). Historical fire and bamboo dynamics in western Amazonia. J. Biogeogr. 40, 299-309. doi: 10.1111/jbi.12002

McMichael, C. H., Correa Metrio, A., and Bush, M. B. (2012c). Pre-Columbian fire regimes in lowland tropical rainforests of southeastern Peru. Palaeogeogr. Palaeoclimatol. Palaeoecol. 342-343, 73-83. doi: 10.1016/j.palaeo.2012.05.004

McMichael, C. H., Palace, M. W., and Golightly, M. (2014b). Bamboo-dominated forests and pre-Columbian earthwork formations in south-western Amazonia. J. Biogeogr. 41, 1733-1745. doi: 10.1111/jbi.12325

McMichael, C. H., Palace, M. W., Bush, M. B., Braswell, B., Hagen, S., Neves, E. G., et al. (2014a). Predicting pre-Columbian anthropogenic soils in Amazonia. Proc. R. Soc. B Biol. Sci. 281:20132475. doi: 10.1098/rspb.2013.2475

McMichael, C. H., Piperno, D. R., Bush, M. B., Silman, M. R., Zimmerman, A. R., Raczka, M. F., et al. (2012a). Sparse pre-Columbian human habitation in western Amazonia. Science 336, 1429-1431. doi: 10.1126/science.12 19982

Meggers, B. J. (1957). Environment and culture in the Amazon basin: an appraisal of the theory of environmental determinism. Stud. Hum. Ecol. 71-89.

Meggers, B. J. (1971). Amazonia, Man and Culture in a Counterfeit Paradise. Chicago, IL: Aldine.

Miller, E. T. (1992). “Adaptação agrícola pré-histórica no alto rio Madeira," in Prehistoria Sudamericana: Nuevas Perspectivas, ed B. Meggers (Washington DC: Taraxacum), 219-232.

Morrison, A. C., Minnick, S. L., Rocha, C., Forshey, B. M., Stoddard, S. T., Getis, A., et al. (2010). Epidemiology of dengue virus in Iquitos, Peru 1999 to 2005: interepidemic and epidemic patterns of transmission. PLoS Negl. Trop. Dis. 4:e670. doi: 10.1371/journal.pntd.0000670

Neves, E. G. (2013). "Was agriculture a key productive activity in pre-colonial amazonia? The stable productive basis for social equality in the Central Amazon," in Human-Environment Interactions, eds E. S. Brondizio and E. F. Moran (Dordrecht: Springer), 371-388.

Neves, E. G., Petersen, J. B., Bartone, R. N., and Heckenberger, M. J. (2004). “The timing of terra preta formation in the central Amazon: Archaeological data from three sites," in Amazonian Dark Earths: Explorations in Space and Time, eds B. Glaser and W. I. Woods (Berlin: Springer), 125-133. doi: 10.1007/978-3662-05683-7_9

Neves, E., and Petersen, J. (2006). "Political economy and pre-columbian landscape transformation in Central Amazonia," in Time and Complexity in Historical Ecology: Studies in the Neotropical Lowlands, eds W. Balee and C. L. Erickson (New York, NY: Columbia University Press), 279-310.

Pärssinen, M., Schaan, D., and Ranzi, A. (2009). Pre-Columbian geometric earthworks in the upper Purús: a complex society in western Amazonia. Antiquity 83, 1084-1095. doi: 10.1017/S0003598X00099373

Piperno, D. R. (2006). Phytoliths: A Comprehensive Guide for Archaeologists and Paleoecologists. Lanham, MD: Alta Mira Press. 
Piperno, D. R. (2007). "Preshistoric human occupation and impacts on Neotropical forest landscapes during the Late Pleistocene and Early/Middle Holocene," in Tropical Rainforest Response to Climatic Change, eds M. B. Bush and J. R. Flenley (Chichester: Springer), 185-212.

Piperno, D. R. (2011). The origins of plant cultivation and domestication in the New World tropics. Curr. Anthropol. 52, S453-S470. doi: 10.1086/659998

Piperno, D. R., and Becker, P. (1996). Vegetational history of a site in the Central Amazon basin derived from phytolith and charcoal records from natural soils. Q. Res. 45, 202-209. doi: 10.1006/qres.1996.0020

Piperno, D. R., McMichael, C., and Bush, M. B. (2015). Amazonia and the Anthropocene: what was the spatial extent and intensity of human landscape modification in the Amazon Basin at the end of prehistory? Holocene 25, 1588-1597. doi: 10.1177/0959683615588374

Pitman, N. (2008). An Overview of the Los Amigos Watershed, Madre de Dios, Southeastern Peru. Washington, DC: Draft report for Amazon Conservation Association.

Pitman, N. C. A., Terborgh, J., Silman, M. R., and Nuñez, P. (1999). Tree species distributions in an upper Amazonian forest. Ecology 80, 2651-2661.

Quesada, C., Lloyd, J., Anderson, L., Fyllas, N., Schwarz, M., and Czimczik, C. (2011). Soils of Amazonia with particular reference to the RAINFOR sites. Biogeosciences 8, 1415-1440. doi: 10.5194/bg-8-1415-2011

Quinn, G. P., and Keough, M. J. (2002). Experimental design and data analysis for biologists. Cambridge, UK: Cambridge University Press. doi: $10.1017 /$ cbo9780511806384

Ranzi, A., Feres, R., and Brown, F. (2007). Internet software programs aid in search for Amazonian geoglyphs. Eos Trans. 88, 226-229. doi: 10.1029/2007EO 210003

Reimer, P. J., Bard, E., Bayliss, A., Beck, J. W., Blackwell, P. G., Ramsey, C. B., et al. (2013). IntCal13 and Marine13 radiocarbon age calibration curves 0-50,000 years cal BP. Radiocarbon 55, 1869-1887. doi: 10.2458/azu_js_rc.55.16947

Rivas, S., Oyuela-Caycedo, A., and Zimmerman, A. R. (2006). Informe preliminar sobre los hallazgos en el sitio arqueologico de Quistococha, Amazonia, Peruana. Bol. Estudios Amazonicos, Unidade de Grado de Ciencias Soc. Univ. Nacional Mayor de San Marcos 1, 79-97.

Roosevelt, A. C. (2013). The Amazon and the Anthropocene: 13,000 Years of human influence in a tropical rainforest. Anthropocene 4, 69-87. doi: 10.1016/j.ancene.2014.05.001

Roosevelt, A. C., Housley, R. A., Imazio da Silveira, M., Maranca, S., and Johnson, R. (1991). Eighth millennium pottery from a prehistoric shell midden in the Brazilian Amazon. Science 254, 1621-1624. doi: 10.1126/science.254.5038.1621

Roosevelt, A. C., Lima da Costa, M., Lopes Machado, C., Michab, M., Mercier, N., Valladas, H., et al. (1996). Paleoindian cave dwellers in the Amazon: the peopling of the Americas. Science 272, 373-384. doi: 10.1126 /science.272.5260.373

Roucoux, K. H., Lawson, I. T., Jones, T. D., Baker, T. R., Coronado, E. N. H., Gosling, W. D., et al. (2013). Vegetation development in an Amazonian peatland. Palaeogeogr. Palaeoclimatol. Palaeoecol. 374, 242-255. doi: 10.1016/j.palaeo.2013.01.023

Rull, V., and Montoya, E. (2014). Mauritia flexuosa palm swamp communities: natural or human-made? A palynological study of the Gran Sabana region (northern South America) within a neotropical context. Q. Sci. Rev. 99, 17-33. doi: 10.1016/j.quascirev.2014.06.007

Sanford, R. L., Saldarriaga, J., Clark, K. E., Uhl, C., and Herrera, R. (1985). Amazon rain-forest fires. Science 227, 53-55. doi: 10.1126/science.227. 4682.53

Sanford, R. L. Jr., and Horn, S. P. (2000). "Holocene rain-forest wilderness: a neotropical perspective on humans as an exotic, invasive species," in Wilderness Science in a Time of Change, eds D. Cole and S. F. McCool (Ogden, UT: US Department of Agriculture. Forest Service Proceedings RMRS-P-15-Vol-3).
Santos, G. M., Gomes, P. R. S., Anjos, R. M., Cordeiro, R. C., Turcq, B. J., Sifeddine, A., et al. (2000). ${ }^{14} \mathrm{C}$ AMS dating of fires in the central Amazon rain forest. Nucl. Instrum. Methods Phys. Res. B 172, 761-766. doi: 10.1016/S0168583X(00)00234-2

Schaan, D., Pärssinen, M., Saunaluoma, S., Ranzi, A., Bueno, M., and Barbosa, A. (2012). New radiometric dates for pre-Columbian $(2000-700 \mathrm{BP})$ earthworks in western Amazonia, Brazil. J. Field Archaeol. 37, 132-142. doi: $10.1179 / 0093469012 \mathrm{Z} .00000000012$

Shepard, G. H., and Ramirez, H. (2011). "Made in Brazil": human dispersal of the brazil nut (Bertholletia excelsa, Lecythidaceae) in ancient Amazonia. Econ. Bot. 65, 44-65. doi: 10.1007/s12231-011-9151-6

Silman, M. R. (2007). "Plant species diversity in Amazonia," in Tropical Rainforests and Climate Change, eds M. B. Bush and J. R. Flenley (Chichester, UK: Praxis), 269-288. doi: 10.1007/978-3-540-48842-2_10

Silman, M. R., Ancaya, E. J., and Brinson, J. (2003). "Los Bosques De Bambú en la Amazonía Occidental," in Alto Purus: Biodiversity, Conservation, and Management, eds R. Leite, N. C. A. Pitman, and P. Alvarez (Durham, NC: Center for Tropical Conservation Press), 63-73.

Silman, M. R., and Krisel, C. (2006). Getting to the root of tree neighbourhoods: hectare-scale root zones of a neotropical fig. J. Trop. Ecol. 22, 727-730. doi: $10.1017 /$ S0266467406003658

Sosnowska, J., Walanus, A., and Balslev, H. (2015). Asháninka palm management and domestication in the Peruvian Amazon. Hum. Ecol. 1-16. doi: 10.1007/s10745-015-9745-1

ter Steege, H., Pitman, N. C., Sabatier, D., Baraloto, C., Salomão, R. P., Guevara, J. E., et al. (2013). Hyperdominance in the Amazonian tree flora. Science 342:1243092. doi: $10.1126 /$ science. 1243092

Terborgh, J. (1990). “An overview of research at Cocha Cashu biological station,” in Four Neotropical Rainforests, ed A. H. Gentry (New Haven, CT: Yale University Press), 48-59.

Terborgh, J. (1992). Diversity and the Tropical Rain Forest. New York, NY: Freeman.

Thomas, E., Alcázar Caicedo, C., McMichael, C. H., Corvera, R., and Loo, J. (2015). Uncovering spatial patterns in the natural and human history of Brazil nut (Bertholletia excelsa) across the Amazon Basin. J. Biogeogr. 42, 1367-1382. doi: $10.1111 /$ jbi. 12540

Tinner, W., Hofstetter, S., Zeugin, F., Conedera, M., and Wohlgemuth, T. (2006). Long-distance transport of macroscopic charcoal by an intensive crown fire in the Swiss Alps-implications for fire history reconstruction. Holocene 16, 287-292. doi: 10.1191/0959683606hl925rr

Tuomisto, H., Ruokolainen, K., and Yli-Halla, M. (2003). Dispersal, environment, and floristic variation of western Amazonian forests. Science 299, 241-244. doi $10.1126 /$ science. 1078037

Weng, C. (2005). An improved method for quantifying sedimentary charcoal via a volume proxy. Holocene 15, 298-301. doi: 10.1191/0959683605hl795rr

Whittaker, R. H., Levin, S. A., and Root, R. B. (1973). Niche, habitat, and ecotope. Am. Nat. 321-338. doi: 10.1086/282837

Conflict of Interest Statement: The authors declare that the research was conducted in the absence of any commercial or financial relationships that could be construed as a potential conflict of interest.

Copyright (C) 2015 McMichael, Piperno, Neves, Bush, Almeida, Mongeló and Eyjolfsdottir. This is an open-access article distributed under the terms of the Creative Commons Attribution License (CC BY). The use, distribution or reproduction in other forums is permitted, provided the original author(s) or licensor are credited and that the original publication in this journal is cited, in accordance with accepted academic practice. No use, distribution or reproduction is permitted which does not comply with these terms. 